(C) The Author(s), 2021. Published by Cambridge University Press on behalf of the Arizona Board of Regents on behalf of the University of Arizona. This is an Open Access article, distributed under the terms of the Creative Commons Attribution licence (http://creativecommons.org/licenses/by/4.0/), which permits unrestricted re-use, distribution, and reproduction in any medium, provided the original work is properly cited.

\title{
REVENIA-KORINOS: ONE OF THE EARLIEST NEOLITHIC SETTLEMENTS IN NORTH GREECE AS EVIDENCED BY RADIOCARBON DATING
}

\author{
Yannis Maniatis $^{1 *}$ (i) Fotini Adaktylou ${ }^{2}$ \\ ${ }^{1}$ Laboratory of Archaeometry, Institute of Nanoscience and Nanotechnology, NCSR "Demokritos", 15310 Aghia \\ Paraskevi, Attiki, Greece \\ ${ }^{2}$ Ministry of Culture, Ephorate of Antiquities of Chalkidiki and Mount Athos, Konstantinoupoleos 5, 63100 \\ Polygyros, Chalkidiki, Greece
}

\begin{abstract}
Radiocarbon $\left({ }^{14} \mathrm{C}\right)$ dating was applied to the Neolithic open-air, flat-extended settlement at ReveniaKorinos in Pieria, North Greece. The samples came from the earlier habitation period of the settlement, characterized by more than 100 pits that vary significantly in shape and dimensions, some of them being identified as subterranean or semi-subterranean pit dwellings. It is suggested that the fills of the pits were the result of secondary, structured refuse deposition, except for pits that preserve their habitational use, according to stratigraphic data. The ${ }^{14} \mathrm{C}$ results confirm that Revenia is among the earliest Neolithic settlements in North Greece and the Aegean in general. The initial phase of habitation is dated at around 6600/6550 $\mathrm{BC}$ comparable only to two other EN sites in North Greece. Habitation intensified at around 6460/6430 BC, accompanied by a shift in pottery style. This phase lasts until $6200 / 6100$ BC when the pit habitation mode is followed by aboveground, rectangular post-framed structures. The dates of the human burials from Revenia also identify them as among the earliest Neolithic burials in Greece. Finally, the radiocarbon dates proved very useful for sequencing the chronological use of the pits and the excavated area in general.
\end{abstract}

KEYWORDS: Early Neolithic, North Greece, Pieria, pit dwellings, radiocarbon dating, Revenia-Korinos.

\section{INTRODUCTION}

The Early Neolithic settlement of Revenia-Korinos is situated in lowland Pieria in northern Greece at Lat. $40^{\circ} 19^{\prime} 29.88^{\prime \prime} \mathrm{N}$ and Long. 22 $33^{\prime} 55.96^{\prime \prime} \mathrm{E}$ (center of the excavated area), about $31 \mathrm{~m}$ above present-day sea level, northwest of the modern village of Korinos and about $5 \mathrm{~km}$ from the current shoreline (Figure 1). The site was discovered during the construction of a poultry farm, and the rescue excavation took place in 2002-2004.

The aim of this study is to perform a systematic radiocarbon dating of the site, in order to determine, in absolute time, the beginning of settling of the first farmers in the area and their subsequent phases of occupation. The aim is also to compare the dates with other Early Neolithic sites in North Greece, an area where some of the earliest settlements of farmers/stock-breeders in Europe were established.

The Neolithic settlement of Revenia belongs to the open-air, flat-extended type of sites excavated during the last 25 years that fill a gap in research into the earlier phases of the Neolithic in Macedonia (Andreou et al. 2001; Kotsakis 2001, 2003, 2005; Kotsos and Urem-Kotsou 2006; Kotsakis 2014). The excavated area covered $850 \mathrm{~m}^{2}$, while the extent of the whole settlement was estimated at 4 ha. There are two different habitation modes at Revenia: subterranean pit dwellings and above-ground, rectangular post-framed structures.

The pit dwellings represent the earlier habitation period, in which, on the base of pottery style, two chronological phases can be distinguished by comparison with the better-known

\footnotetext{
*Corresponding author. Email: y.maniatis@inn.demokritos.gr
} 


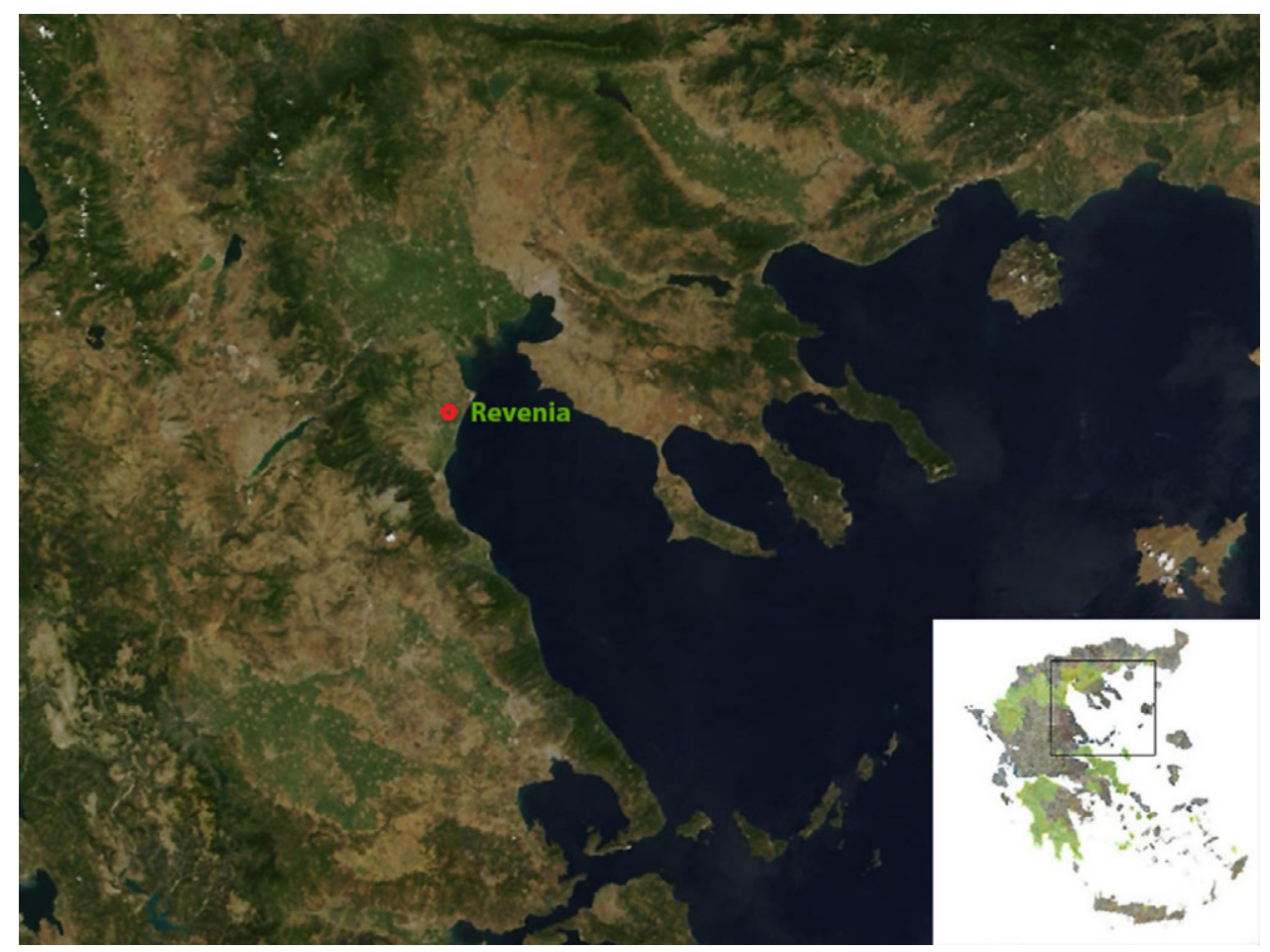

Figure 1 General map of Greece and zoomed inlet showing the exact position of Revenia site.

Thessalian sequence: an earlier Early Neolithic phase (EEN) and a later Early Neolithic phase (LEN). The habitation period with the above-ground, rectangular post-framed structures is dated only to the second phase (LEN) of the settlement.

Pit habitation is represented by more than 100 pits, cut into the natural bedrock (Figure 2). The pits vary significantly in shape and dimensions, from 0.5 to more than $5 \mathrm{~m}$ diameter and up to $1.68 \mathrm{~m}$ surviving depth. Based on construction elements (e.g., size, associated postholes, occasionally burnt clay remains of the superstructure and other features), a number of pits were characterized as subterranean or semi-subterranean pit dwellings, while others as possible working areas and refuse pits (Figure 3). The fills of individual pits also vary greatly, with some rich in ceramics (Figure 4A-C), and others in animal bones. "Ear studs," artifacts characteristic mostly of the early phases of Neolithic, are also present (Figure 4D), with fourteen found in pit 44. It is suggested that the fills of most, if not all, of the pits were the result not of random discard but of structured deposition (for a general assessment of this issue see Chapman 2000, 2010; Chapman et al. 2014). This structured deposition is also observed spatially: pits filled mainly with pottery are located to the northwest, center and southeast of the excavated area, while pits that lacked pottery but contained animal bones, and pits that contained very few finds are located to the northeast (Figure 5).

The habitation period characterized by above-ground, rectangular post-framed structures is poorly preserved and is located over the pits or close to them (Besios and Adaktylou 2006; Adaktylou 2017) (Figure 6). 


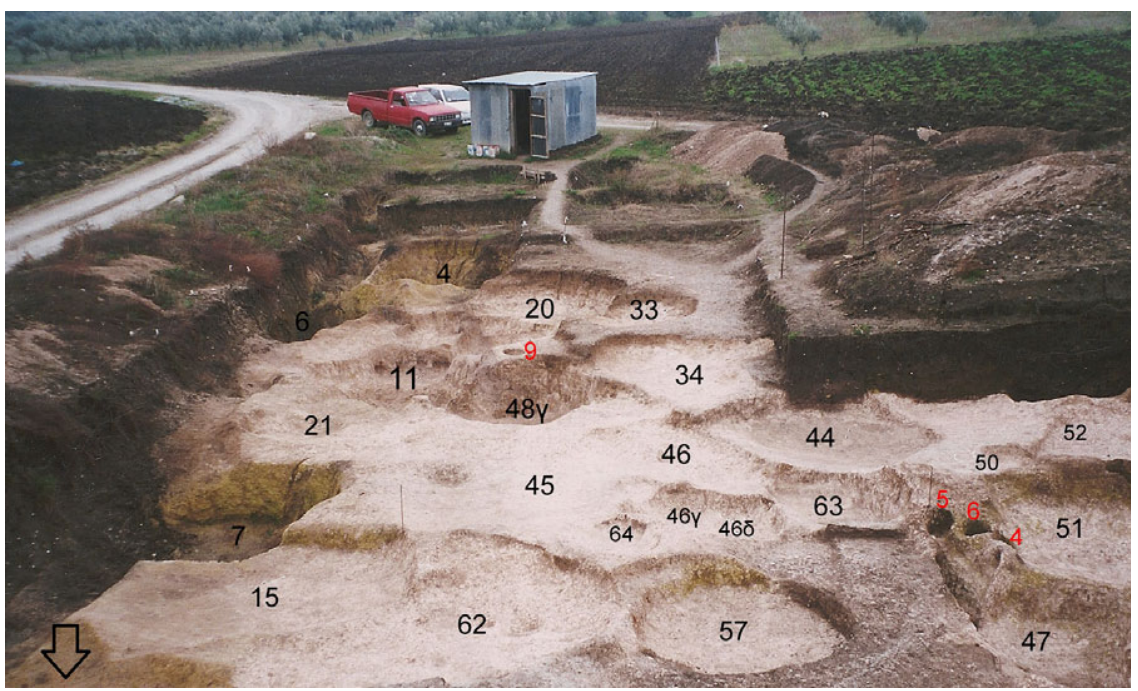

Figure 2 A photo of the site during the excavation showing the characteristic pits.

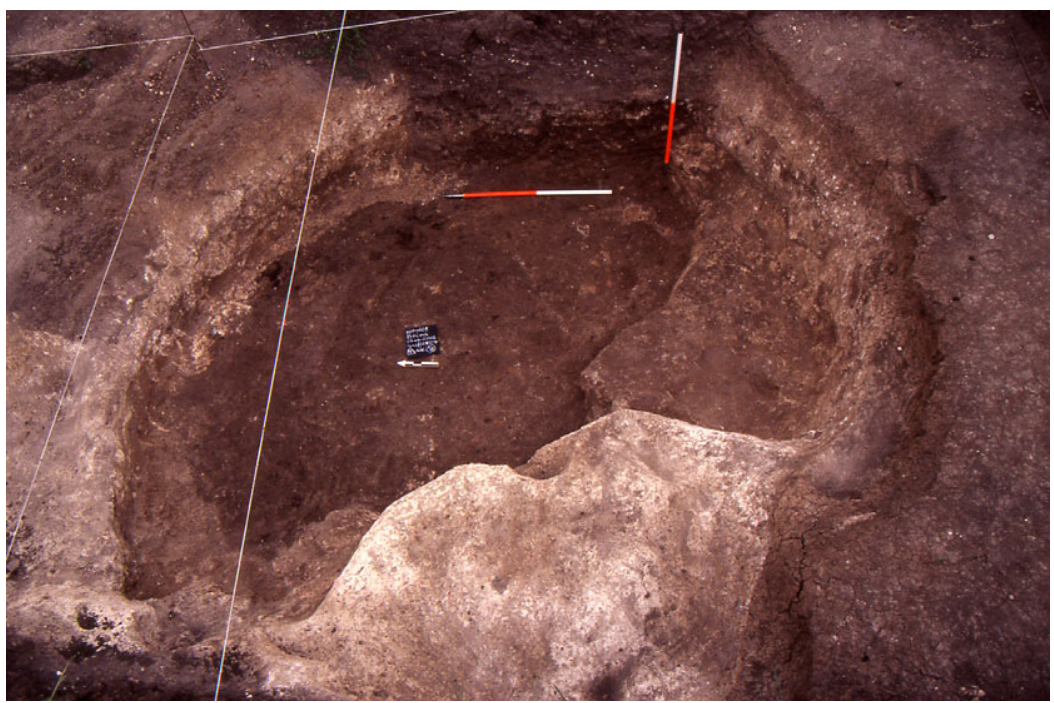

Figure 3 Habitation pit 5 with access steps.

The well-defined contexts from Revenia have yielded rich assemblages of several categories of skilfully manufactured artifacts and also of ecofacts, which indicate a settlement where early agriculture (Kotzamani 2009) and livestock management (Isaakidou et al. 2018) were practiced. The inhabitants of Revenia communicated and interacted with other settlements, participating in exchange networks, as pottery analysis (Urem-Kotsou et al. 2017) and the presence of obsidian in large quantities (Dogiama 2017) indicate.

There were also 11 human burials excavated, seven of which were primary articulated inhumations (Figure 7) and four secondary disarticulated inhumations. Twelve cases of 


\section{A}

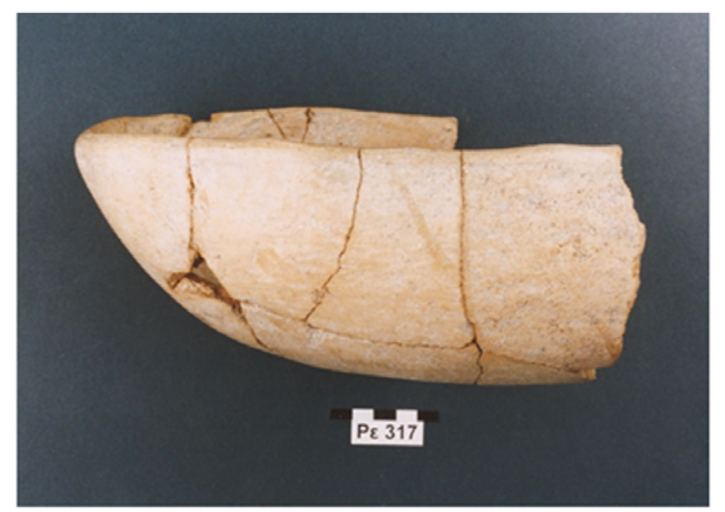

B

C
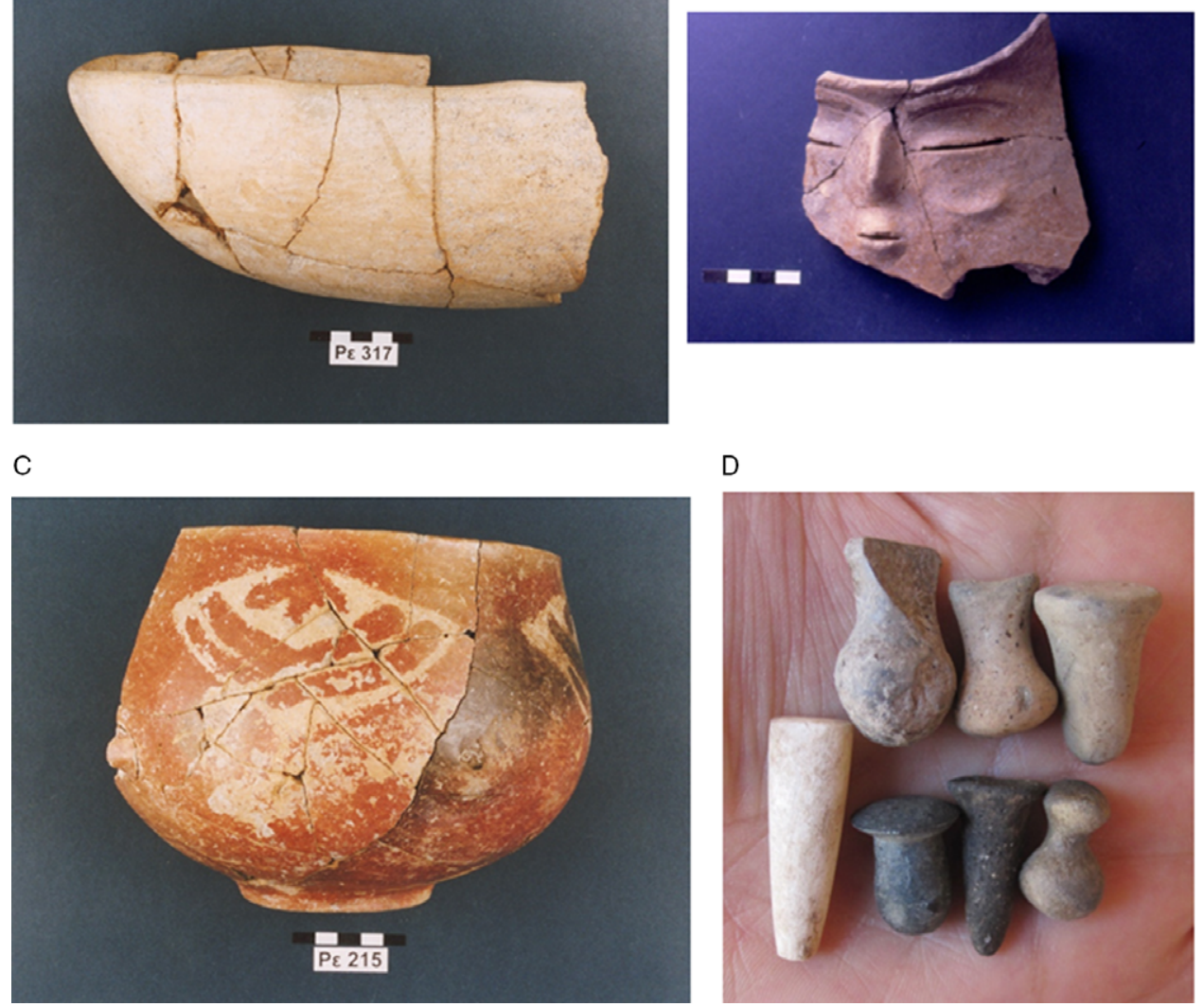

$\mathrm{D}$

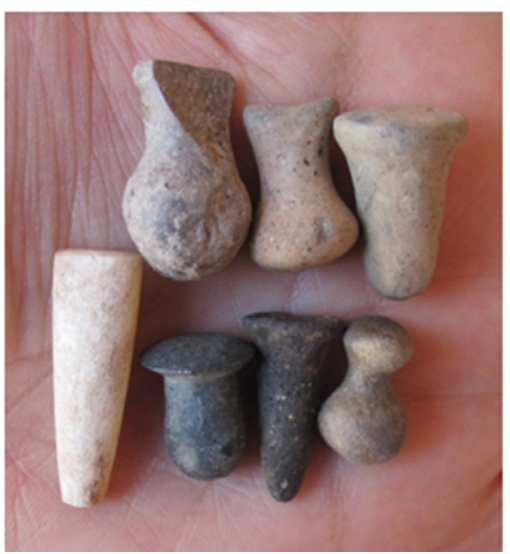

Figure 4 Finds from the pits: A: monochrome boat-shaped pot, $102 \times 230 \mathrm{~mm}$ (habitation pit 7); B: anthropomorphic pot, $108 \times 100 \mathrm{~mm}$ (habitation pit 2); C: pot with painted decoration, $155 \times 310$ mm (habitation pit 26); D: "ear studs," max length $20 \mathrm{~mm}$.

scattered human bones were also found in some of the pits of the settlement. The dating of a fair number of them was included in this study, enriching our knowledge of mortuary practices from the earliest phases of the Neolithic in Macedonia, suggesting high diversity in the treatment of the deceased and multiple negotiations taking place between the living and the dead (Triantaphyllou and Adaktylou 2019).

One of the Revenia EN burials, with others from northern Greece and northwestern Turkey, was included in a paleogenetic study which "demonstrates a direct genetic link between Mediterranean and Central European early farmers and those of Greece and Anatolia, extending the European Neolithic migratory chain all the way back to southwestern Asia" (Hofmanová et al. 2016).

\section{SAMPLES AND METHODS}

Thirty (30) samples were selected from the pits, representing the earliest and more advanced phases of the settlement (EEN and LEN), and subjected to radiocarbon dating. Of these, eleven 


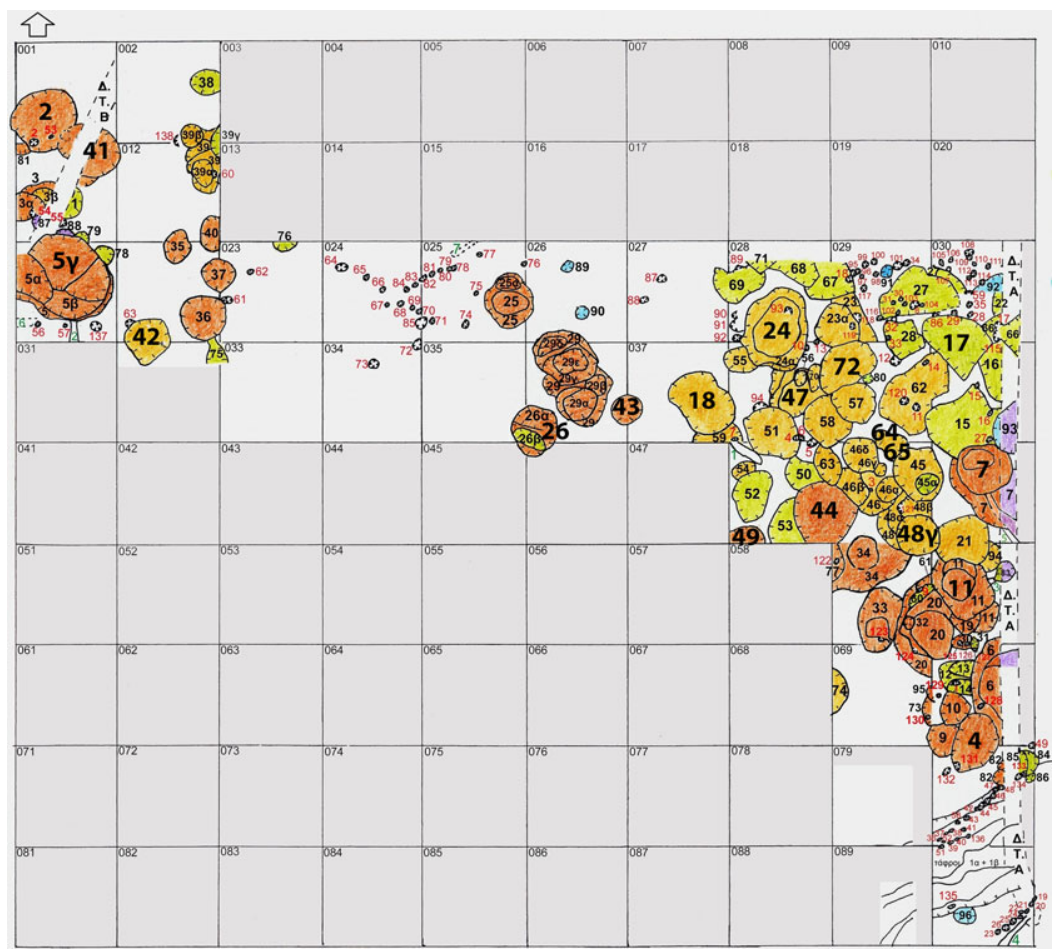

Figure 5 Plan of the excavation at Revenia. Each square measures $5 \times 5 \mathrm{~m}$. Color code: red-brown = pits filled mainly with pottery, but also cockles, animal bones, and a variety of small finds; yellow = pits that lacked pottery and contained animal bones, bone, chipped stone and ground stone tools; pale green = pits that contained very few finds. (Please see electronic version for color figures.)

(11) were burnt organic matter (charcoal), eight (8) animal bone, ten (10) human bone, and one (1) charred seed.

A list of all samples with their excavation units, locations and contextual associations is presented in Table 1 . With the primary aim of covering the full range of the pit habitation period and the different uses of the pits, the selected samples include: a) 12 of 22 pits identified as habitation pits (pits 2, 4, 5, 7, 11, 24, 26, 41, 42, 44, 48y and 72); b) 2 of 5 pits with pottery that mostly lacks decoration, a common, although extensively debated, characteristic of the early phase of the EN, according to the Thessalian ceramic typology (Urem-Kotsou et al. 2017: 325-328) (habitation pits 7 and 44); c) 6 of 32 pits containing no pottery, or just very few sherds mainly from their upper levels (pits 18 and 47, and habitation pits 24,42,48 $\gamma$ and 72); d) habitation pit 26, containing cattle bones that suggest EN ploughing, judging by "pathologies" compatible with traction-induced stress"; e) pit 18, containing large quantities of chipped stone tools, and habitation pits 2 and 41 , containing extraordinarily large quantities of the brackish-water cockle Cerastoderma glaucum (Krahtopoulou and Veropoulidou 2014, 2016); f) pit 49, from a layer rich in burnt daub remains.

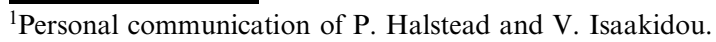




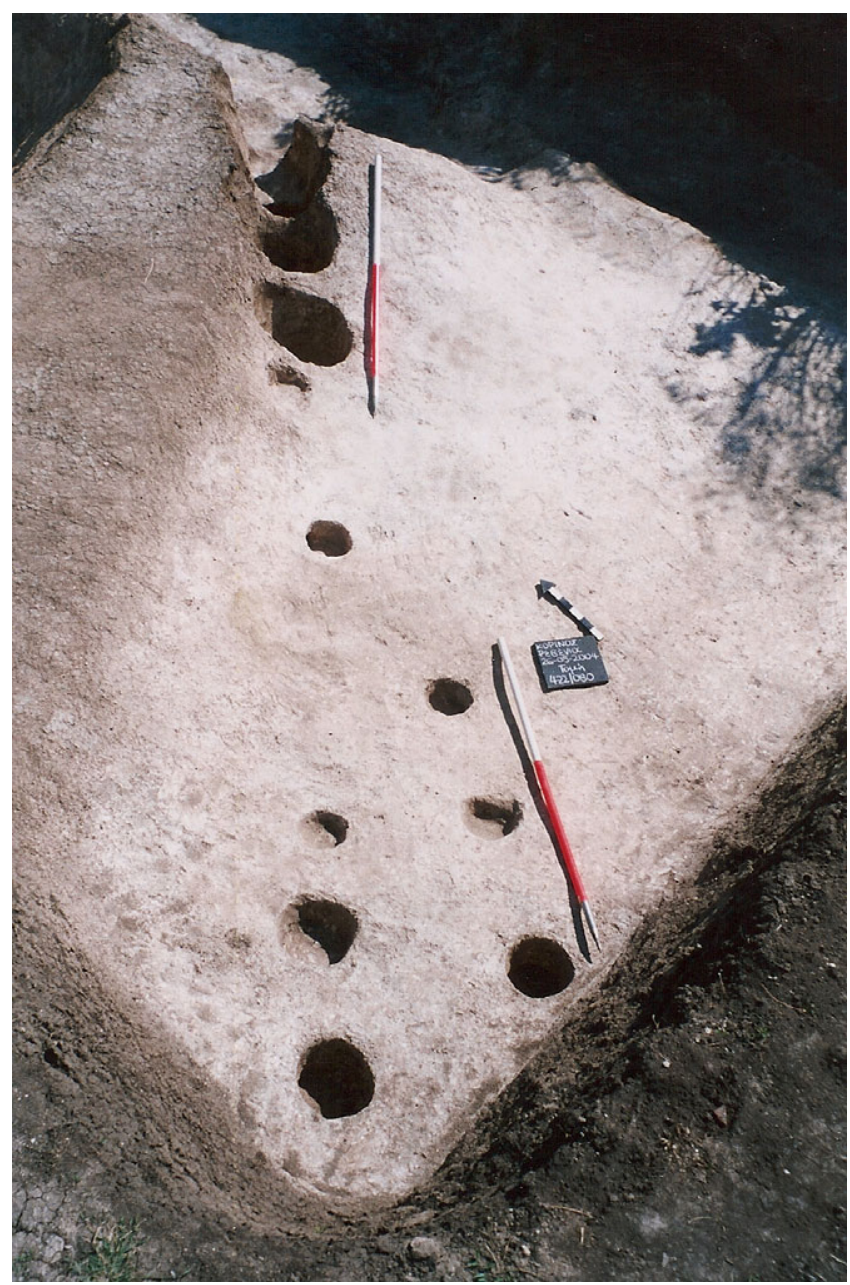

Figure 6 Postholes from the habitation mode with above-ground, rectangular post-framed buildings.

Regarding the human burials, an interesting part of the overall study, we dated seven of the 11 primary articulated and secondary disarticulated inhumations, and two scattered human bones. In particular, five articulated burials were dated. Four of these come from habitation pit 11 (DEM-2886: probably woman 30-40 years old; DEM-2824: man 33-35 years old; DEM-2888: woman 40-50 years old; DEM-2930: infant 2-2.5 years old), after its transformation into a funerary area, while two (DEM-2824 and DEM-2886) yielded clear evidence of secondary manipulation of the dead body. The fifth primary articulated burial comes from burial pit 43 (DEM-2890: woman 40-50 years old). The two secondary disarticulated inhumations (bone accumulations) were found in burial pit 43 (DEM-2891: child 6-7 years old) and in the vicinity of pits 64 and 65 (DEM-2889: woman in late $30 \mathrm{~s})$. Finally, the two scattered human bones that were dated come from pit 17 (DEM-2892: probably man in late 40s) and habitation pit 24 (DEM-2826: adult) (Triantaphyllou and Adaktylou 2019). 


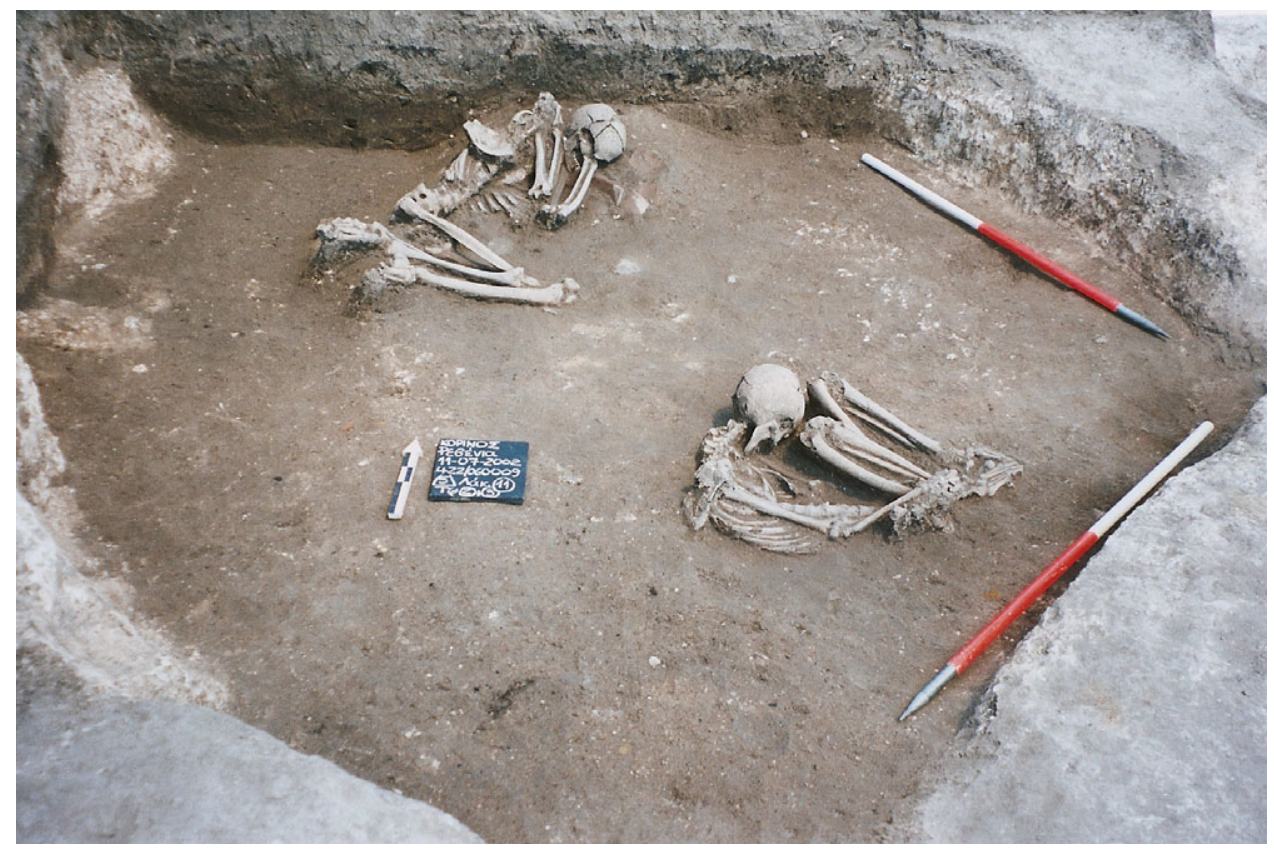

Figure 7 Articulated human burials 2 and 3 in habitation pit 11.

An additional concern was to crosscheck some of the dates, by sampling different kinds of material from the same pit: charcoal and animal bone from habitation pit 2; charcoals and animal bone from habitation pit 7; and animal bone, human bone and seed from habitation pit 24 .

The size of the samples prohibited conventional radiometric dating except for two larger charcoal samples (DEM-2375 and DEM-2376). Hence, after an initial examination under the microscope and mechanical separation, cleaning, photographing and archiving at the Laboratory of Archaeometry of NCSR Demokritos in Athens, 28 charcoal, bone and the seed samples were sent for further processing and dating to the AMS facility of Klaus-Tschira-Labor für Physikalische Altersbestimmung, Curt-Engelhorn-Zentrum Archaeometrie gGmbH, Mannheim. The two larger charcoal samples were processed and measured at the Laboratory of Archaeometry of NCSR Demokritos, which uses the Gas Proportional Counting (GPC) technique.

The procedures used for sample preparation and measurement at the Curt-Engelhorn-Zentrum Archaeometrie, Mannheim are briefly: 1) bone: the collagen is extracted from the bone samples using a modified Longin method (Longin 1971; Brown et al. 1988), purified by ultrafiltration (fraction $>30 \mathrm{kD}$ ) and freeze-dried; 2) charcoal/seed: the samples are pretreated using the ABA-method (acid/base/acid, $\mathrm{HCl} / \mathrm{NaOH} / \mathrm{HCl}$ ). The insoluble fraction is used for further treatment. The treated samples are combusted to $\mathrm{CO}_{2}$ in an Elemental Analyzer (EA), and the $\mathrm{CO}_{2}$ is then converted catalytically to graphite. The ${ }^{14} \mathrm{C}$ content is measured using a MICADAS-type AMS system in-house. The isotopic ratios ${ }^{14} \mathrm{C} /{ }^{12} \mathrm{C}$ and ${ }^{13} \mathrm{C} /{ }^{12} \mathrm{C}$ of samples, calibration standard (Oxalic Acid-II), blanks and control standards are measured simultaneously in the AMS. The ${ }^{14} \mathrm{C}$ ages are normalized to $\delta^{13} \mathrm{C}=-25 \%$ (Stuiver and Polach 1977). 
Table 1 All Revenia samples processed: The excavation units, context, material, as well as the $\mathrm{C} / \mathrm{N}$ ratio for collagen and percent sample combusted, together with the radiocarbon age and calibrated $2 \sigma$ range (unmodeled) in calendar years BC. The samples are ordered according to pit number.

\begin{tabular}{|c|c|c|c|c|c|c|}
\hline Lab code & $\begin{array}{l}\text { Excavation unit } \\
\text { and area }\end{array}$ & Context/pottery phase & Material & $\begin{array}{c}\mathrm{C} / \mathrm{N} \text { or mass } \\
\text { combusted and } \\
(\% \text { Carbon })\end{array}$ & $\begin{array}{l}{ }^{14} \mathrm{C} \text { age } \\
(\mathrm{BP})\end{array}$ & $\begin{array}{l}\text { Calibrated } \\
\text { age } 2 \sigma \\
(\mathrm{CalBC})\end{array}$ \\
\hline $\begin{array}{l}\text { DEM-2825 } \\
\text { (MAMS-23277) }\end{array}$ & $\begin{array}{l}\text { Habitation pit } 2 \\
422001008 \\
\text { Elevation: } \\
\text { 29.54-29.35 m }\end{array}$ & $\begin{array}{l}\text { Primary } \\
\text { habitation phase }\end{array}$ & $\begin{array}{l}\text { Animal bone } \\
\text { (Domestic } \\
\text { cattle humerus) }\end{array}$ & $3.1(35.5 \%)$ & $7727 \pm 29$ & $6630-6480$ \\
\hline DEM-2376 & $\begin{array}{l}\text { Habitation pit } 2 \\
422001007 \\
\text { Elevation: } 29.61 \mathrm{~m}\end{array}$ & $\begin{array}{l}\text { Secondary } \\
\text { structured refuse } \\
\text { deposition / LEN pottery }\end{array}$ & $\begin{array}{l}\text { Charcoal } \\
\text { (Maloideae) }\end{array}$ & $1.75 \mathrm{~g}(100 \%)$ & $7493 \pm 30$ & $6435-6255$ \\
\hline DEM-2375 & $\begin{array}{l}\text { Habitation pit } 4 \\
422070005 \\
\text { Elevation: } 28.07 \mathrm{~m}\end{array}$ & $\begin{array}{l}\text { Secondary } \\
\text { structured refuse } \\
\text { deposition / } \\
\text { LEN pottery }\end{array}$ & $\begin{array}{l}\text { Charcoal } \\
\text { (Quercus sp. } \\
\text { deciduous type) }\end{array}$ & $2.33 \mathrm{~g}(100 \%)$ & $7348 \pm 30$ & $6342-6087$ \\
\hline $\begin{array}{l}\text { DEM-2746 } \\
\text { (MAMS-20226) }\end{array}$ & $\begin{array}{l}\text { Habitation pit } 5 \gamma \\
422021004 \\
\text { Elevation: } 29.50 \mathrm{~m}\end{array}$ & $\begin{array}{l}\text { Secondary structured } \\
\text { refuse deposition / } \\
\text { LEN pottery }\end{array}$ & $\begin{array}{l}\text { Charcoal } \\
\text { (Quercus sp. } \\
\text { deciduous type) }\end{array}$ & $3.6 \mathrm{mg}(60 \%)$ & $7447 \pm 25$ & $6392-6247$ \\
\hline $\begin{array}{l}\text { DEM-2753 } \\
\text { (MAMS-20219) }\end{array}$ & $\begin{array}{l}\text { Habitation pit } 7 \\
422050005 \\
\text { Elevation: } 27.60 \mathrm{~m}\end{array}$ & $\begin{array}{l}\text { Secondary } \\
\text { structured refuse } \\
\text { deposition / } \\
\text { EEN pottery }\end{array}$ & $\begin{array}{l}\text { Charcoal } \\
\text { (Quercus sp. } \\
\text { deciduous type) }\end{array}$ & $4.3 \mathrm{mg}(59 \%)$ & $7444 \pm 26$ & $6391-6245$ \\
\hline $\begin{array}{l}\text { DEM-2754 } \\
\text { (MAMS-20218) }\end{array}$ & $\begin{array}{l}\text { Habitation pit } 7 \\
422050005 \\
\text { Elevation: } 27.34 \mathrm{~m}\end{array}$ & $\begin{array}{l}\text { Secondary } \\
\text { structured refuse } \\
\text { deposition / } \\
\text { EEN pottery }\end{array}$ & $\begin{array}{l}\text { Charcoal } \\
\text { (Quercus sp.) }\end{array}$ & $3.5 \mathrm{mg}(59 \%)$ & $7428 \pm 25$ & $6378-6237$ \\
\hline $\begin{array}{l}\text { DEM-2817 } \\
\text { (MAMS-23269) }\end{array}$ & $\begin{array}{l}\text { Habitation pit } 7 \\
422050014 \\
\text { Elevation: } \\
27.23-26.57 \mathrm{~m}\end{array}$ & $\begin{array}{l}\text { Secondary } \\
\text { structured refuse } \\
\text { deposition / } \\
\text { EEN pottery }\end{array}$ & $\begin{array}{l}\text { Animal bone } \\
\text { (Domestic } \\
\text { cattle tibia) }\end{array}$ & $3.2(29.2 \%)$ & $7397 \pm 27$ & $6367-6224$ \\
\hline
\end{tabular}




\begin{tabular}{|c|c|c|c|c|c|c|}
\hline Lab code & $\begin{array}{l}\text { Excavation unit } \\
\text { and area }\end{array}$ & Context/pottery phase & Material & $\begin{array}{l}\mathrm{C} / \mathrm{N} \text { or mass } \\
\text { combusted and } \\
(\% \text { Carbon })\end{array}$ & $\begin{array}{l}{ }^{14} \mathrm{C} \text { age } \\
\text { (BP) }\end{array}$ & $\begin{array}{l}\text { Calibrated } \\
\text { age } 2 \sigma \\
(\text { CalBC })\end{array}$ \\
\hline $\begin{array}{l}\text { DEM-2886 } \\
\text { (MAMS-24564) }\end{array}$ & $\begin{array}{l}\text { Habitation pit } 11 \\
\text { Human burial } 2 \\
\text { (trial trench } \mathrm{A} \text { ), } \\
422060 \\
\text { Elevation: } 0.75 \mathrm{~m} \\
\text { from the existing } \\
\text { ground surface }\end{array}$ & $\begin{array}{l}\text { Funerary area / } \\
\text { LEN pottery }\end{array}$ & $\begin{array}{l}\text { Human bone } \\
\text { (Hand phalanx) }\end{array}$ & $3.2(34.2 \%)$ & $7541 \pm 31$ & $6461-6373$ \\
\hline $\begin{array}{l}\text { DEM-2824 } \\
\text { (MAMS-23276) }\end{array}$ & $\begin{array}{l}\text { Habitation pit } 11 \\
\text { Human burial } 2 \\
422060010 \\
\text { Elevation: } 27.91 \mathrm{~m}\end{array}$ & $\begin{array}{l}\text { Funerary area / } \\
\text { LEN pottery }\end{array}$ & $\begin{array}{l}\text { Human bone } \\
\text { (Hand phalanx) }\end{array}$ & $3.1(38.1 \%)$ & $7503 \pm 28$ & $6439-6261$ \\
\hline $\begin{array}{l}\text { DEM-2888 } \\
\text { (MAMS-24566) }\end{array}$ & $\begin{array}{l}\text { Habitation pit } 11 \\
\text { Human burial } 3 \\
422060011 \\
\text { Elevation: } 28.01 \mathrm{~m}\end{array}$ & $\begin{array}{l}\text { Funerary area / } \\
\text { LEN pottery }\end{array}$ & $\begin{array}{l}\text { Human bone } \\
\text { (Hand phalanx) }\end{array}$ & $3.2(30.7 \%)$ & $7503 \pm 30$ & $6440-6260$ \\
\hline $\begin{array}{l}\text { DEM-2745 } \\
\text { (MAMS-20227) }\end{array}$ & $\begin{array}{l}\text { Habitation pit } 11 \\
\quad 422060012 \\
\text { Elevation: } 27.77 \mathrm{~m}\end{array}$ & $\begin{array}{l}\text { Secondary } \\
\text { structured refuse } \\
\text { deposition / } \\
\text { LEN pottery }\end{array}$ & $\begin{array}{l}\text { Charcoal } \\
\text { (Quercus sp. } \\
\text { deciduous type) }\end{array}$ & $4.0 \mathrm{mg}(61 \%)$ & $7404 \pm 27$ & $6370-6227$ \\
\hline $\begin{array}{l}\text { DEM-2930 } \\
\text { (MAMS-26639) }\end{array}$ & $\begin{array}{l}\text { Habitation pit } 11 \\
\text { Human burial } 1 \\
\text { (trial trench A), } \\
422060 \\
\text { Elevation: } 0.45 \mathrm{~m} \\
\text { from the existing } \\
\text { ground surface }\end{array}$ & $\begin{array}{l}\text { Funerary area / } \\
\text { LEN pottery }\end{array}$ & $\begin{array}{l}\text { Human bone } \\
\text { (L tibia) }\end{array}$ & $3.0(32.3 \%)$ & $7250 \pm 32$ & $6216-6036$ \\
\hline
\end{tabular}




\begin{tabular}{|c|c|c|c|c|c|c|}
\hline Lab code & $\begin{array}{l}\text { Excavation unit } \\
\text { and area }\end{array}$ & Context/pottery phase & Material & $\begin{array}{l}\mathrm{C} / \mathrm{N} \text { or mass } \\
\text { combusted and } \\
\text { (\%Carbon) }\end{array}$ & $\begin{array}{c}{ }^{14} \mathrm{C} \text { age } \\
(\mathrm{BP})\end{array}$ & $\begin{array}{l}\text { Calibrated } \\
\text { age } 2 \sigma \\
\text { (CalBC) }\end{array}$ \\
\hline $\begin{array}{l}\text { DEM-2892 } \\
\text { (MAMS-24570) }\end{array}$ & $\begin{array}{l}\text { Pit } 17 \text {, } \\
\text { Scattered human } \\
\text { bone } \\
422040008 \\
\text { Elevation: } 27.66 \mathrm{~m}\end{array}$ & $\begin{array}{l}\text { Secondary } \\
\text { structured refuse } \\
\text { deposition/unidentified } \\
\text { sherds from the upper } \\
\text { layers }\end{array}$ & $\begin{array}{l}\text { Human bone } \\
\text { (Cranial } \\
\text { fragment) }\end{array}$ & $3.0(27.0 \%)$ & $7518 \pm 31$ & $6452-6265$ \\
\hline $\begin{array}{l}\text { DEM-2818 } \\
\text { (MAMS-23270) }\end{array}$ & $\begin{array}{l}\text { Pit } 18 \\
\text { 422037001 } \\
\text { Elevation: } \\
\text { 29.06-28.62 m }\end{array}$ & $\begin{array}{l}\text { Secondary } \\
\text { structured refuse } \\
\text { deposition/unidentified } \\
\text { sherds from the upper } \\
\text { layers }\end{array}$ & $\begin{array}{l}\text { Animal bone } \\
\text { (Domestic } \\
\text { cattle tibia) }\end{array}$ & $3.2(30.7 \%)$ & $7618 \pm 28$ & $6502-6428$ \\
\hline $\begin{array}{l}\text { DEM-2822 } \\
\text { (MAMS-23274) }\end{array}$ & $\begin{array}{l}\text { Habitation pit } 24 \\
422038014 \\
\text { Elevation: } \\
27.83-27.53 \mathrm{~m}\end{array}$ & $\begin{array}{l}\text { Secondary } \\
\text { structured refuse } \\
\text { deposition/unidentified } \\
\text { sherds from the upper } \\
\text { layers }\end{array}$ & $\begin{array}{l}\text { Animal bone } \\
\text { (Domestic } \\
\text { cattle humerus) }\end{array}$ & $3.2(33.5 \%)$ & $7643 \pm 29$ & $6569-6437$ \\
\hline $\begin{array}{l}\text { DEM-2826 } \\
\text { (MAMS-23278) }\end{array}$ & $\begin{array}{l}\text { Habitation pit } 24 \\
\text { Scattered human } \\
\text { bone } \\
422028003 \\
\text { Elevation: } 27.80 \mathrm{~m}\end{array}$ & $\begin{array}{l}\text { Secondary } \\
\text { structured refuse } \\
\text { deposition/unidentified } \\
\text { sherds from the upper } \\
\text { layers }\end{array}$ & $\begin{array}{l}\text { Human bone } \\
\quad \text { (Fragment of } \\
\text { R tibia) }\end{array}$ & $3.1(28.3 \%)$ & $7642 \pm 26$ & $6567-6437$ \\
\hline $\begin{array}{l}\text { DEM-2827 } \\
\text { (MAMS-23279) }\end{array}$ & $\begin{array}{l}\text { Habitation pit } 24 \\
422038014 \\
\text { Elevation: } 27.73 \mathrm{~m}\end{array}$ & $\begin{array}{l}\text { Secondary } \\
\text { structured refuse } \\
\text { deposition/unidentified } \\
\text { sherds from the upper } \\
\text { layers }\end{array}$ & $\begin{array}{l}\text { Seed } \\
\text { (Hordeum } \\
\text { vulgare })\end{array}$ & $4.2 \mathrm{mg}(58.6 \%)$ & $7486 \pm 26$ & $6429-6256$ \\
\hline
\end{tabular}




\begin{tabular}{|c|c|c|c|c|c|c|}
\hline Lab code & $\begin{array}{l}\text { Excavation unit } \\
\text { and area }\end{array}$ & Context/pottery phase & Material & $\begin{array}{l}\mathrm{C} / \mathrm{N} \text { or mass } \\
\text { combusted and } \\
(\% \text { Carbon })\end{array}$ & $\begin{array}{l}{ }^{14} \mathrm{C} \text { age } \\
\text { (BP) }\end{array}$ & $\begin{array}{l}\text { Calibrated } \\
\text { age } 2 \sigma \\
(\text { CalBC })\end{array}$ \\
\hline $\begin{array}{l}\text { DEM-2819 } \\
\text { (MAMS-23271) }\end{array}$ & $\begin{array}{l}\text { Habitation pit } 26 \\
422036003 \\
\text { Elevation: } \\
29.23-28.62 \mathrm{~m}\end{array}$ & $\begin{array}{l}\text { Secondary } \\
\text { structured refuse } \\
\text { deposition / LEN pottery }\end{array}$ & $\begin{array}{l}\text { Animal bone } \\
\text { (Domestic } \\
\text { cattle tibia) }\end{array}$ & $3.2(26.3 \%)$ & $7393 \pm 27$ & $6368-6222$ \\
\hline $\begin{array}{l}\text { DEM-2820 } \\
\text { (MAMS-23272) }\end{array}$ & $\begin{array}{l}\text { Habitation pit } 41 \\
422011010 \\
\text { Elevation: } \\
\text { 30.00-29.66 m }\end{array}$ & $\begin{array}{l}\text { Primary } \\
\text { habitation phase }\end{array}$ & $\begin{array}{l}\text { Animal bone } \\
\quad \text { (Pig humerus) }\end{array}$ & $3.2(30.5 \%)$ & $7686 \pm 28$ & $6591-6467$ \\
\hline $\begin{array}{l}\text { DEM-2749 } \\
\text { (MAMS-20223) }\end{array}$ & $\begin{array}{l}\text { Habitation pit } 42 \\
\text { 422022012 } \\
\text { Elevation: } 29.76 \mathrm{~m}\end{array}$ & $\begin{array}{l}\text { Secondary } \\
\text { structured refuse } \\
\text { deposition/unidentified } \\
\text { sherds from the upper } \\
\text { layers }\end{array}$ & $\begin{array}{l}\text { Charcoal } \\
\text { (Quercus sp.) }\end{array}$ & $4.4 \mathrm{mg}(58 \%)$ & $7616 \pm 27$ & $6497-6429$ \\
\hline $\begin{array}{l}\text { DEM-2750 } \\
\text { (MAMS-20222) }\end{array}$ & $\begin{array}{l}\text { Habitation pit } 42 \\
\text { 422032003 } \\
\text { Elevation: } 29.76 \mathrm{~m}\end{array}$ & $\begin{array}{l}\text { Secondary } \\
\text { structured refuse } \\
\text { deposition/unidentified } \\
\text { sherds from the upper } \\
\text { layers }\end{array}$ & $\begin{array}{l}\text { Charcoal } \\
\text { (Quercus sp. } \\
\text { deciduous type) }\end{array}$ & $4.3 \mathrm{mg}(63 \%)$ & $7603 \pm 29$ & $6480-6423$ \\
\hline $\begin{array}{l}\text { DEM-2890 } \\
\text { (MAMS-24568) }\end{array}$ & $\begin{array}{l}\text { Burial pit } 43 \\
\text { Human burial } 5 \\
422036017 \\
\text { Elevation: } 28.68 \mathrm{~m}\end{array}$ & Burial pit / LEN pottery & $\begin{array}{l}\text { Human bone } \\
\text { (Hand phalanx) }\end{array}$ & $2.9(38.5 \%)$ & $7453 \pm 30$ & $6400-6242$ \\
\hline $\begin{array}{l}\text { DEM-2891 } \\
\text { (MAMS-24569) }\end{array}$ & $\begin{array}{l}\text { Burial pit } 43 \\
\text { Human burial } 6 \\
422036015 \\
\text { Elevation: } 28.79 \mathrm{~m}\end{array}$ & Burial pit / LEN pottery & $\begin{array}{l}\text { Human bone } \\
\text { (Fragment of } \\
\text { R fibula })\end{array}$ & $3.0(25.2 \%)$ & $7345 \pm 32$ & $6341-6083$ \\
\hline
\end{tabular}




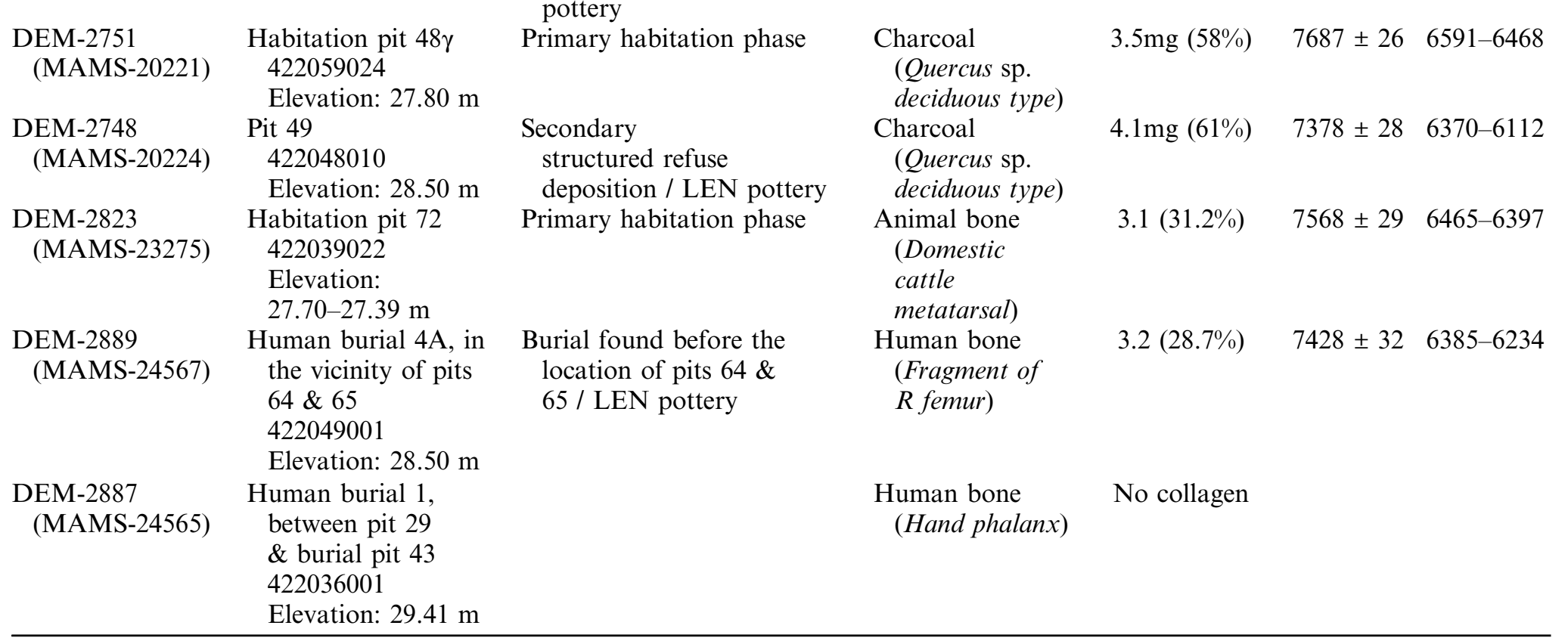


The procedures used for sample preparation and measurement of the charcoal samples at the Laboratory of Archaeometry, NCSR Demokritos in Athens can be found in detail in Maniatis et al. (2016). Briefly, the samples are pretreated using the ABA-method (acid/base/acid, 4\% $\mathrm{HCl} / 4 \% \mathrm{NaOH} / 4 \% \mathrm{HCl}$ ). They are then combusted using a de Vries-type (de Vries and Barendsen 1953) continuous combustion system and converted to $\mathrm{CO}_{2}$. All other oxides are removed by reaction with $\mathrm{KMnO}_{4}$, and the $\mathrm{CO}_{2}$ is precipitated to calcium carbonate in a $\mathrm{CaCl}_{2} / \mathrm{NH}_{4}$ solution. Subsequently, the samples are again turned into $\mathrm{CO}_{2}$ and any remaining impurities in the gas, including radon $(\mathrm{Rn})$, are removed by passing the sample through activated charcoal. The activity of ${ }^{14} \mathrm{C}$ is measured in a series of cylindrical gas proportional counters (Kromer and Münnich 1992). Blanks and standard samples are run frequently in the counters. The isotopic ratio ${ }^{13} \mathrm{C} /{ }^{12} \mathrm{C}$ is measured separately from an aliquot of the $\mathrm{CO}_{2}$ sample in an IRMS spectrometer. The ${ }^{14} \mathrm{C}$ ages are normalized to $\delta^{13} \mathrm{C}$ $=-25 \%$ (Stuiver and Polach 1977).

All radiocarbon ages are calibrated using the OxCal v.4.3.2 program with the dataset IntCal13 (Reimer et al. 2013).

\section{RESULTS AND DISCUSSION}

\section{Dating the Full Range of the Settlement's Habitation Period}

Table 1 summarizes all the results, including the collagen $\mathrm{C} / \mathrm{N}$ ratio for bones and the amount of sample combusted for charcoal, plus the per cent of carbon (in parenthesis) calculated for each sample after combustion. The samples are ordered according to pit number and in each pit according to depth (from deeper to shallower). One sample of human bone (DEM-2887) produced no collagen, and so the final number of dated samples is 29 .

A multi-plot of the unmodeled calibrated probability distributions of all the dated samples is shown in Figure 8, in order of radiocarbon age, with type of material sampled (charcoal, animal bone, human bone, or seed) denoted by color.

As demonstrated by this plot and Table 1, the dates of the samples range from 6553 BC (mean oldest date, DEM-2825) to 6128 BC (mean youngest date, DEM-2930), spanning some 400 years of habitation in the pits. The earliest dates come from the habitation phases of pit 2 (DEM-2825), pit 48y (DEM-2751), and pit 41 (DEM-2820).

Figure 9 shows the $S U M$ output of the calibrated probability distributions. This plot shows that the initial phase of habitation begins sometime between 6600 and $6550 \mathrm{BC}$, followed by a rapid increase in habitation intensity, at least in the excavated area, after $6500 \mathrm{BC}$ and reaching a peak at around $6460 \mathrm{BC}$. Thereafter radiocarbon indications of habitation remain constantly high until about $6230 \mathrm{BC}$, when they decline rapidly, to continue at a very low intensity until shortly after $6100 \mathrm{BC}$. The overall distribution of the $S U M$ function could be influenced by the selection of samples and/or wiggles in the calibration curve. The selection of samples should not be a problem, however, as these were chosen to represent all different types and expected dates of pits. The wiggles may extend the older and younger ends of the distribution artificially, but, as discussed above, the oldest mean date at $6553 \mathrm{BC}$ and the youngest mean at $6128 \mathrm{BC}$ are included in the overall $S U M$ distribution and safely confirm its end points. 
Revenia (Black=Ch., Blue=Animal, Red=Human, Mag.=Seed)

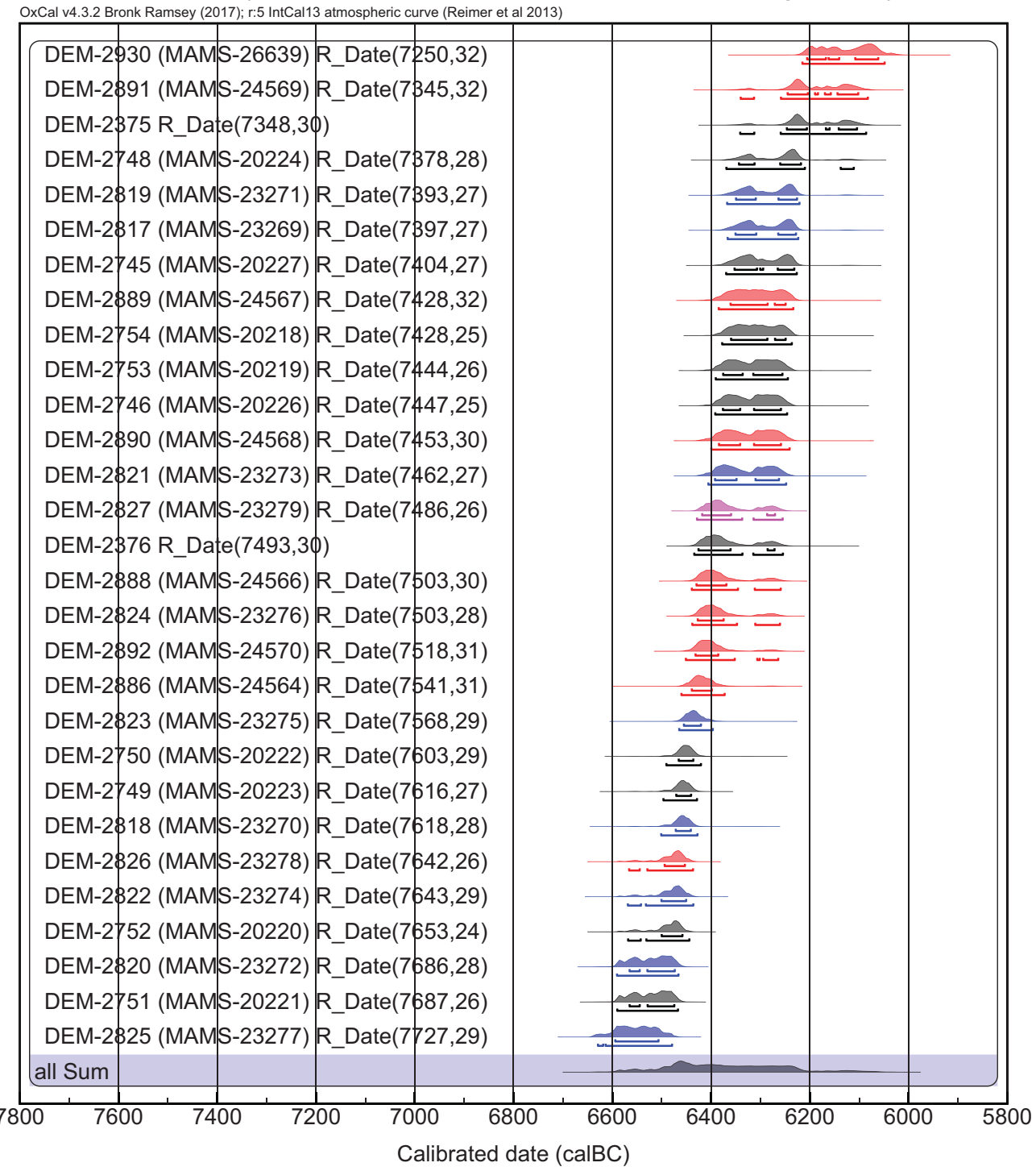

Figure 8 A multi-plot showing the calibrated dates probability distributions of all the Revenia samples (OxCal program v.4.3.2, Bronk Ramsey 2017). Color code: black = charcoal; blue = animal bone; red $=$ human bone; magenta $=$ seed. (Please see electronic version for color figures.)

Due to the nature of the fills of the pits, which are thought to be mainly the result of secondary, structured refuse deposition, except for pits that preserve traces of their habitational use, the exact correspondence between ceramic phases and samples dated is not always straightforward. In order to attempt a phase analysis model, however, we have selected a number of samples which are securely associated with a certain stratigraphy and/or pottery group.

In particular, as mentioned earlier, two phases can be recognized within the pit habitation mode of settlement; an earlier Early Neolithic (EEN) phase and a more advanced, later 


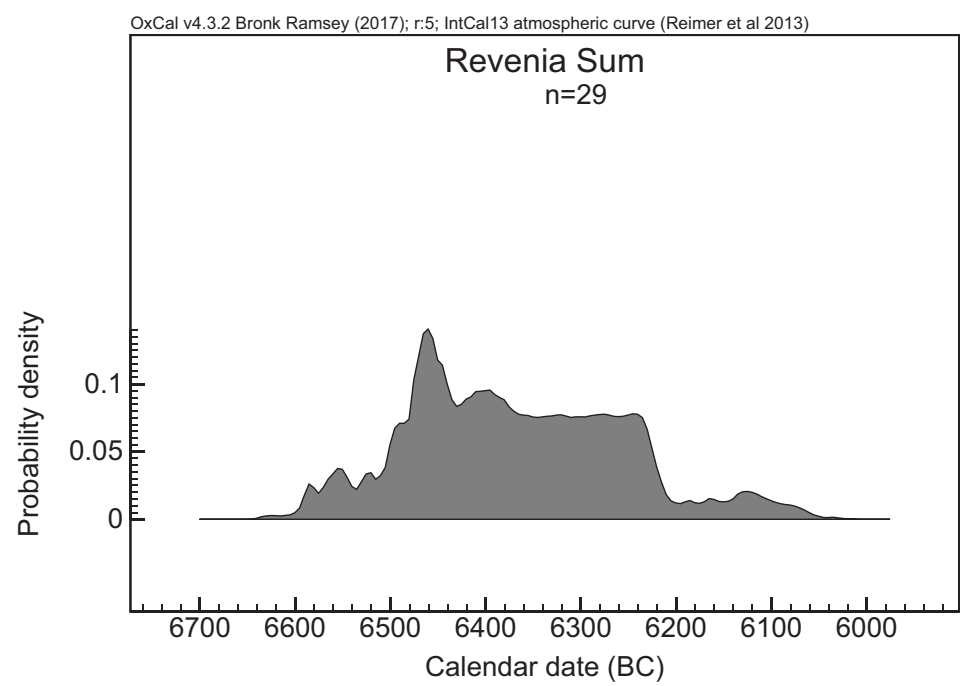

Figure 9 The sum of calibrated probability distributions as derived from the multi-plot of Figure 8.

Early Neolithic (LEN) phase (for an assessment of Early and Middle Neolithic pottery in Macedonia and Thessaly, see Urem-Kotsou et al. 2014, 2017) ${ }^{2}$. The samples that can be securely included in each of these two phases are:

\section{EEN Phase}

The samples DEM-2825 from pit 2 (animal bone), DEM-2751 from pit 48 (charcoal), DEM2820 from pit 41 (animal bone), and DEM-2823 from pit 72 (animal bone) come from their earliest, primary habitation use, according to their stratigraphic history (Table 1, Figure 10). In addition, sample DEM-2752 from pit 47 (charcoal) comes from its secondary phase of structured refuse deposition, where EEN pottery was attested (Table 1).

\section{LEN Phase}

The samples DEM-2376 from pit 2 (charcoal), DEM-2375 from pit 4 (charcoal), DEM-2756 from pit $5 \gamma$ (charcoal), DEM-2886, 2824, 2888, 2930 and 2745 from pit 11 (four human burials and charcoal), DEM-2819 from pit 26 (animal bone), DEM-2890 and 2891 from pit 43 (two human burials), DEM-2748 from pit 49 (charcoal) and DEM-2889 a human burial in the vicinity of pits 64 and 65 come from the secondary, structured refuse deposition phase of the pits, where LEN pottery was attested (Table 1 and Figure 10).

The rest of the samples cannot be securely associated with a specific context. The samples DEM-2892 from pit 17 (scattered human bone), DEM-2818 from pit 18 (animal bone), DEM-2826, 2822, and 2827 from pit 24 (scattered human bone, animal bone and seed) and DEM-2749 and 2750 from pit 42 (two charcoals) come from the secondary, structured refuse deposition phase, where very few inconclusive sherds, mainly from the upper levels

\footnotetext{
${ }^{2}$ In Urem-Kotsou et al. 2017 (p. 328-331), the pottery from the Late Early Neolithic phase and the Early Middle Neolithic phase are presented together, mainly because "the pottery itself, and the material culture in general, do not exhibit a visible break, but rather a gradual process of change while maintaining continuity".
} 


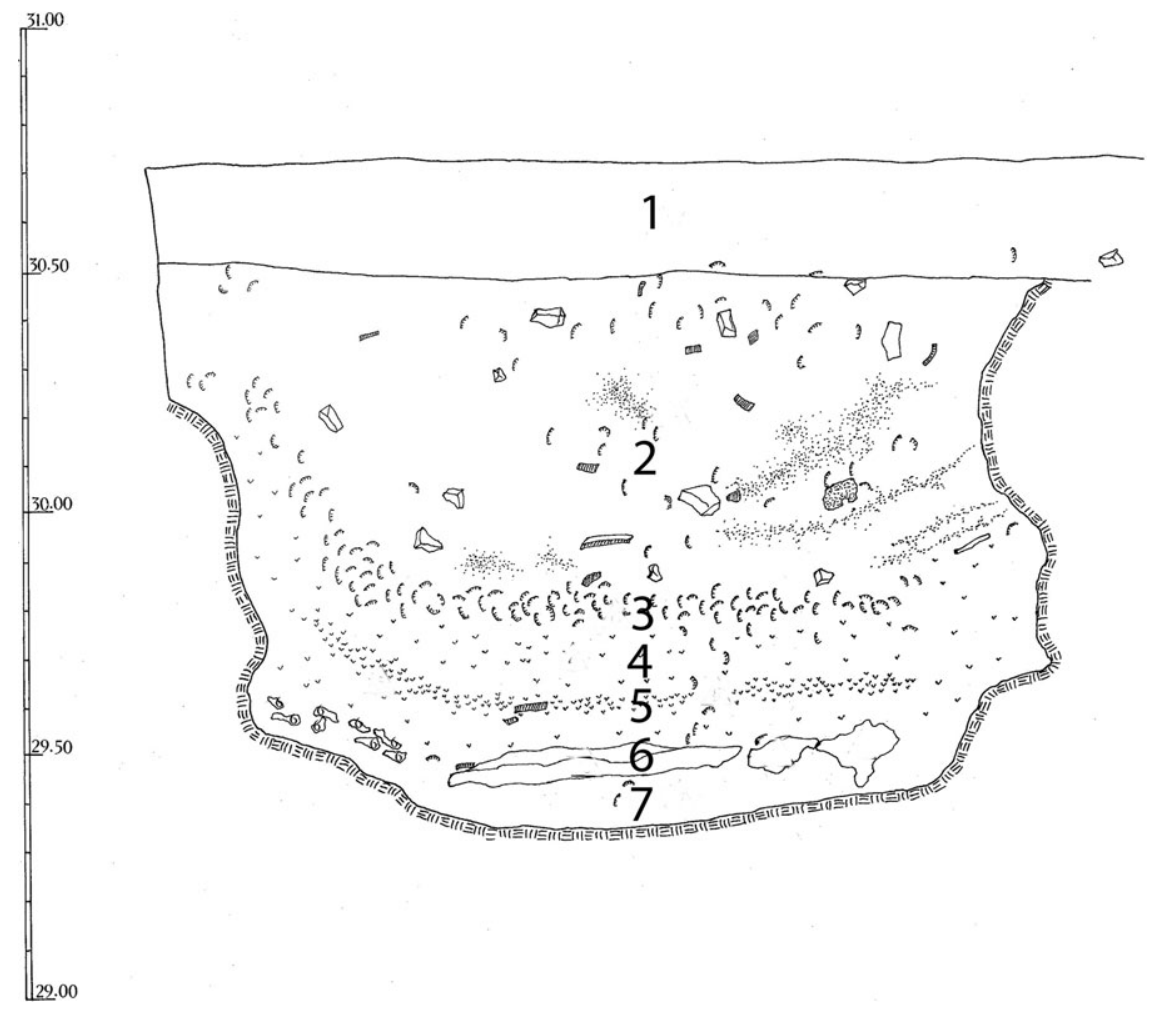

Figure 10 Profile of pit 2: under the surface layer 1, layers 2 (ceramics, cockles, animal bones, and charcoals), 3 (mainly cockles), 4 (scattered charcoals), and 5 (dense charcoals) resulted from secondary, refuse structured deposition. Layer 7 (very few ceramics, cockles and animal bones) belongs to the primary habitation use of the pit. Layer 6 is natural bedrock, fallen from the sidewalls of pit 2 into layer 7.

of the pits, were found. These samples were not included in the phase model. Some comments on the phase to which they may belong are made below.

Finally, the samples DEM-2753, 2754, and 2817 from pit 7 (two charcoals and animal bone) and DEM-2821 from pit 44 (animal bone) come from the secondary, structured refuse deposition phase of the pits, where EEN pottery was attested. However, the organic samples dated from these pits seemed to be later than the pottery associated with the fill. These samples are also not included in the phase model.

Figure 11 shows the output of the Bayesian analysis model (Bronk Ramsey 2009) using two phases with the secure samples discussed above. The agreement of the model is excellent (Aoverall and Amodel = 104.9\%). The numeric output of the model is presented in Table 2. The START of habitation of the settlement is estimated at around $6550 \mathrm{BC}$ with an uncertainty of $50 \mathrm{yrs}$. The TRANSITION from the earliest phase (EEN) to the more advanced (LEN) is estimated around $6430 \mathrm{BC}$ with an uncertainty of $17 \mathrm{yr}$, indicating that the transition is continuous and without any break. Finally, the END of the model, which includes samples of the latest activity in the pit habitation mode, is estimated at $6170 \mathrm{BC}$ with an uncertainty of $36 \mathrm{yr}$. These results indicate that the earliest habitation phase at 
Table 2 Revenia: numerical results of the Bayesian analysis two phase model. All dates in calBC.

\begin{tabular}{lcccc}
\hline Phase & Age range (95.4\%) & Mean & Median & Consensus \\
\hline Start of EEN & $6652-6478$ & 6555 & 6546 & 6550 \\
Transition EEN to LEN & $6462-6396$ & 6429 & 6430 & 6430 \\
End of model & $6223-6091$ & 6169 & 6179 & 6170 \\
\hline
\end{tabular}

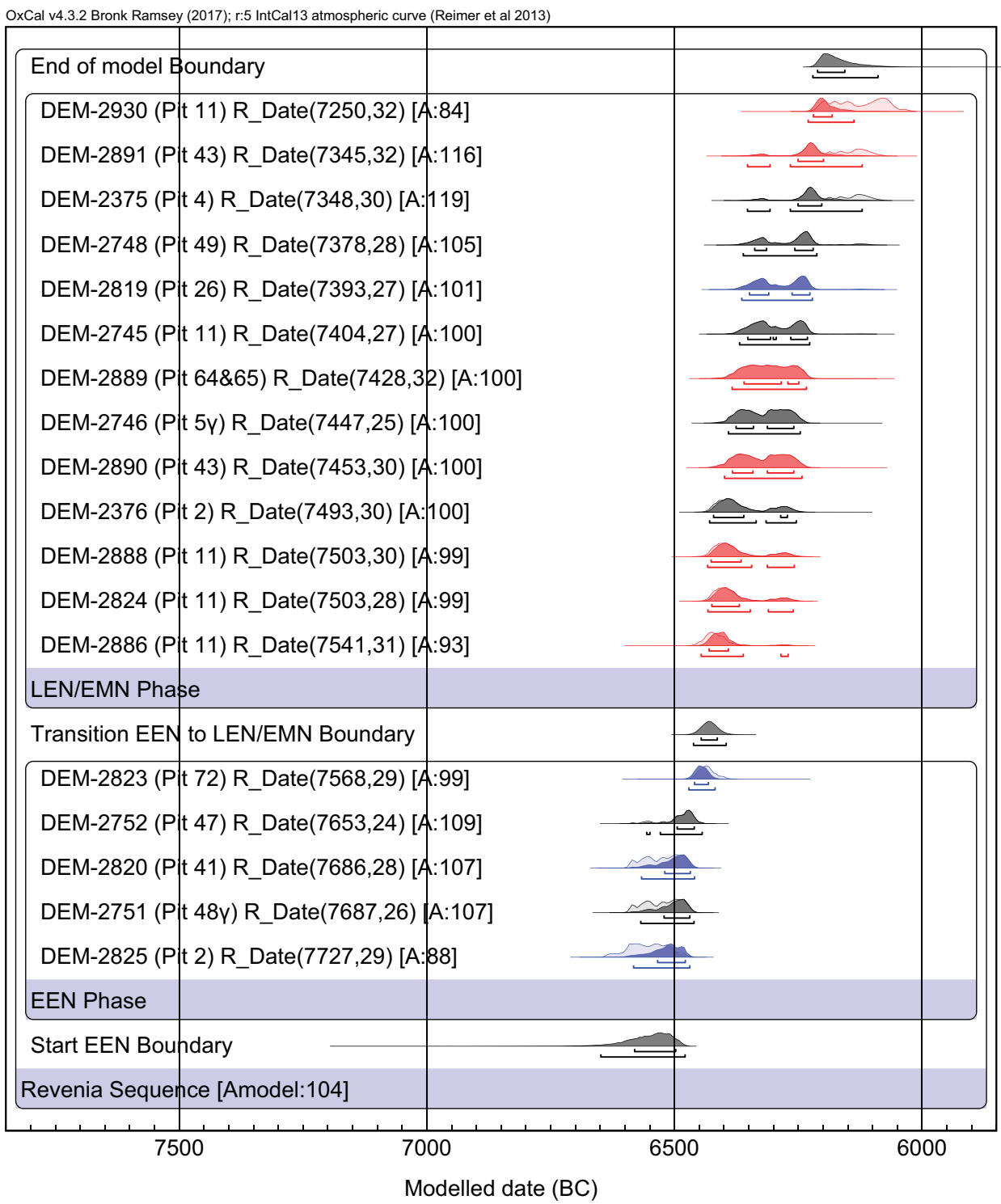

Figure 11 Bayesian analysis with a two-phase model using only samples with secure context performed with OxCal v.4.3.2 (Bronk Ramsey 2009, 2017). Color code: black = charcoal; blue = animal bone; red $=$ human bone. (Please see electronic version for color figures.) 
Revenia (EEN), starting at $6550 \mathrm{BC}$ or a bit earlier according to the distribution of dates (Figures 8, 9, and 11), lasts for about 120 years, while the following more advanced phase (LEN), starting at $6430 \mathrm{BC}$, lasts much longer-for more than 260 years. If these phase analysis results are compared with the $S U M$ function (Figure 9) it becomes clear that the earliest phase (EEN), which begins just after $6600 \mathrm{BC}$, is shorter and represented by a smaller number of samples (and thus perhaps by sparser human activity?). Also, the peak in the frequency of dates observed at around $6460 \mathrm{BC}$, implying a rather abrupt intensification in the use of the area, as reflected in the increased quantity of materials deposited in the pits, coincides with the beginning of the advanced phase (LEN) at a modeled date around 6430 BC (Table 2, Figure 11). This intensification at 6460/6430 BC may reflect a rapid increase of population at the beginning of this phase and persisting until about $6200 \mathrm{BC}$ (Figures 9 and 11). Soon after that date (about 50 years later), pit habitation ends and is followed by the above-ground, rectangular post-framed structures, not radiocarbon dated, but also dating to the LEN period on the base of pottery style in Thessalian terms.

Comparing the Revenia dating results with other sites in North Greece, similarly early dates (a little before $6550 \mathrm{BC}$ ) mark the beginning of EN habitation at Mavropigi-Fillotsairi (Karamitrou-Mentessidi et al. 2013; Maniatis 2014) and Paliambela-Kolindros (Maniatis 2014; Maniatis et al. 2015). Revenia is thus confirmed as one of the few earliest Early Neolithic settlements in North Greece. Equally, the transition from the very early phase (EEN) to a more advanced Early Neolithic phase (LEN) around $6400 \mathrm{BC}$ is also observed at Mavropigi-Fillotsairi and Paliambela-Kolindros.

It is now well established that the primary zone of Neolithization in western Eurasia encompassed the Levant, Taurus-Zagros ranges of Mesopotamia, the Central Fertile Crescent in Turkey and Cyprus (Kilinç et al. 2017; Zeder 2009; Burger and Thomas 2011), where the earliest evidence for sedentary life and food storage date back to about 10,000 BC. Several thousand years later neolithization reached the Aegean and sometime later central Europe. The dates around $6550 \mathrm{BC}$ or slightly earlier for the beginning of EN habitation and farming at Revenia are among the earliest not only in North Greece (together with Mavropigi-Fillotsairi and Paliambela-Kolindros), but also in the whole of mainland Greece and the Aegean (Maniatis 2014; Horejs et al. 2015) ${ }^{3}$, with Thessaly coming a little bit later or about the same time (Reingruber et al. 2017).

There is a lot of ongoing discussion regarding the origin of the Aegean farmers. Archaeogenetic evidence based on aDNA (Hofmanová et al. 2016; Paschou et al. 2014; Haak et al. 2010; Kilinç et al. 2017; Lazaridis et al. 2016, 2017; Hofmann 2015; Mathieson et al. 2015, 2018) suggests an origin in Southwest Asia. This is consistent with evidence from plants and animals whose origins are traced in the primary core regions of the Levantine (Hansen 1991: 141; Burger and Thomas 2011; Weiss and Zohary 2011; Marinova and Valamoti 2014). Furthermore, based on radiocarbon evidence showing the establishment of the first settlements almost at the same time on both sides of the Aegean, but also on genetic evidence showing a "gene flow" from the wider Near East region, and material culture at least for some coastal sites (e.g., Çukuriçi Höyük, Franchthi), a "maritime networking and colonization model" has been proposed (Perlès 2003; Fernandez et al. 2014; Maniatis 2014; Paschou et al. 2014;

\footnotetext{
${ }^{3}$ With the exception of Crete where it seems to occur at around 6650 BC (Douka et al. 2017) and perhaps the cave of Franchthi in Peloponnese where a phase called Initial Neolithic occurs between 7000-6600 BC, although this seems to be an aceramic phase and not directly comparable (Perlès et al 2013).
} 
Horejs et al. 2015). The presence of the farmers quite early in Cyprus and Crete proves their proficiency in sailing.

However, there are questions raised about the Neolithic package from SW Asia to the Aegean, regarding both the human migration and plant transfer, arguing for insufficient DNA data so far or proposing a mixed model of transfer and adaptation (Colledge et al. 2004; Valamoti and Kotsakis 2007; Burger and Thomas 2011) or stressing the complexity, multiplicity and fluidity that characterize the transition to the Neolithic way of life in Greece (Kotsakis 2001, 2003, 2005, 2008; Halstead 2011). Future research may shed light on these very fundamental issues, which however are beyond the scope of this paper.

The site of Revenia-Korinos lay in the vicinity of an estuarine setting: as the sea level continued to rise, a relatively shallow marine embayment was established (Krahtopoulou and Veropoulidou 2014, 2016). Adjacent streams continued to provide fresh water, while alluvial sediments occasionally reached the sea bottom. A similar environmental setting characterizes the coastal/alluvial site of Çukuriçi Höyük on the Anatolian side of the mid/ south Aegean with evidence of early Neolithic arrivals by sea (Horejs et al. 2015). Similarly, the site of Paliambela-Kolindros, just $20 \mathrm{~km}$ north of Revenia, is near the coast of the Thermaic Gulf. In addition, around $6400 \mathrm{BC}$, when the later phase (LEN) emerges at Revenia, several new settlements seem to be established in North Greece such as AxosPellas, Yannitsa-B, Nea Nikomedeia (Reingruber and Thissen 2009; Maniatis 2014) all around the Yannitsa Plain, which was then an extension of the Thermaic Gulf and in combination with the influx of several rivers formed most likely a kind of sea/lake environment (Bintliff 1976; Gkouma and Karkanas 2016). The site of Mavropigi-Filotsairi differs somewhat as situated on an inland elevated plateau $(650 \mathrm{~m}$ asl), but on the western edge of the basin of Kitrini Limni (Yellow Lake) and close to the river Aliakmon. In fact, most of the Neolithic sites discovered so far in north Greece are close to rivers, alluvial plains, lakes, etc. (Wilkie and Savina 1997; Gkouma and Karkanas 2016). Thus, it seems that these types of environments and fertile lands with plenty of water attracted the first farmers from the very early stages of Neolithization as the radiocarbon dating confirms.

The intensification of habitation at Revenia in the LEN phase at about $6400 \mathrm{BC}$, and the establishment of several new sites around the Yannitsa plain and elsewhere [e.g., Dikili Tash in East Macedonia (Lespez et al. 2017)] at the same time are consistent with a population increase. The reasons for this are not known, but some hypotheses can be posed. The increase could be due to a population expansion, perhaps associated with the new way of life, implying the consumption of more plant and animal protein leading to increased life expectancy and better child health, or a second wave of migrant farmers from SW Asia as suggested by Paschou et al. (2014).

After the pit habitation mode is abandoned (around 6200/6100 BC), above-ground, rectangular post-framed structures follow at Revenia, which were built over the pits or close to them. The architectural remains of this habitation mode (not radiocarbon dated) are barely preserved. This habitation period also dates to the second phase (LEN) of the settlement, based on comparison of the pottery with the Thessalian sequence.

\section{Analysis of the Spatial and Temporal Variations in Use of the Pits}

In order to display the chronological distribution of habitation and use of the pits within the site and to detect any possible spatial shifts with time we have constructed Figure 12, which shows 


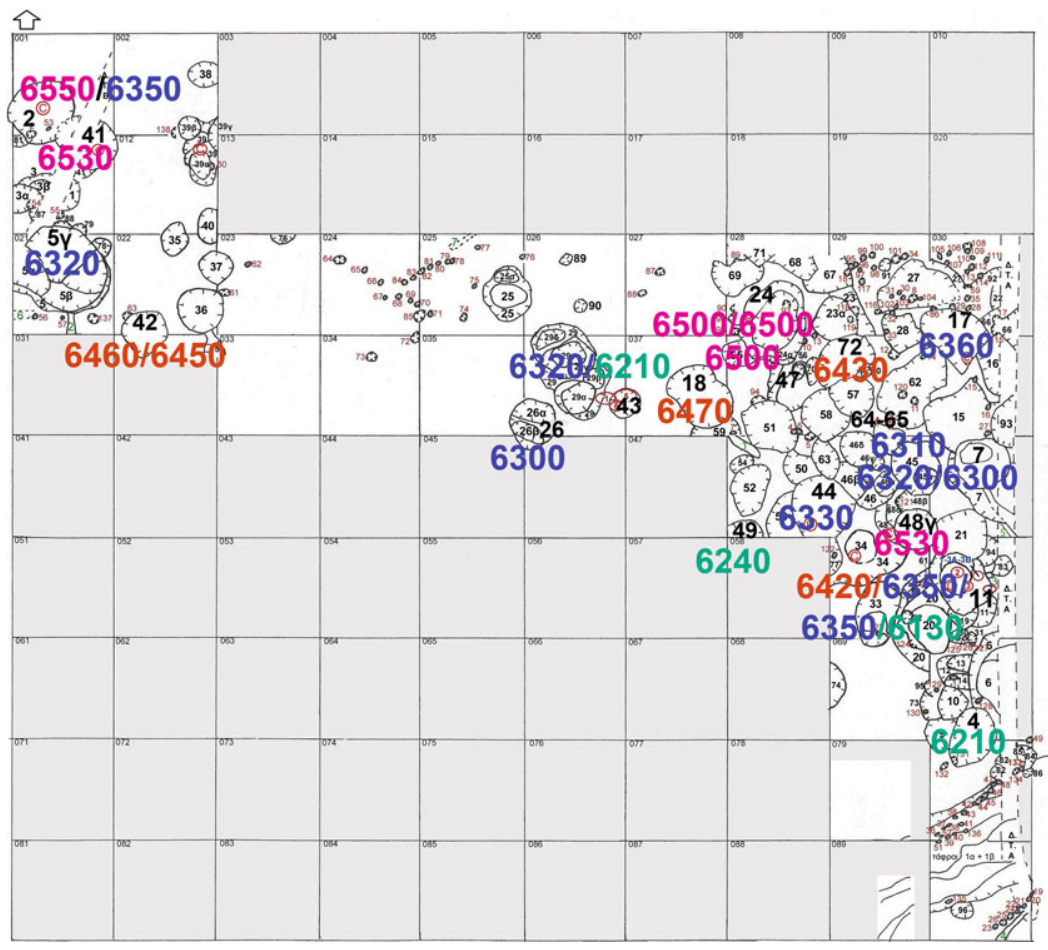

Figure 12 Plan of the spatial distribution of pits at the site with the mean calibrated dates on them. The dates with strokes are from pits with more than one dated sample. Mean dates between 6550-6500 BC representing the first occupation are in magenta, between 6460-6420 BC representing the second phase are in red/brown, between 6350-6300 BC (still a densely populated phase) are in blue, and 6240-6210 BC (the final phase and end of habitation) are in turquoise. Each square measures $5 \times 5 \mathrm{~m}$. (Please see electronic version for color figures.)

the mean calibrated radiocarbon dates on the sampled pits. The earliest dates of occupation (mean dates 6550/6500 BC) appear from one end of the excavated area to the other, covering distances from $5 \mathrm{~m}$ to almost $40 \mathrm{~m}$ apart. The same is true for the second and most intense phase of occupation (mean dates 6470/6420 BC). Later dates, around 6300 $\mathrm{BC}$, also appear in higher levels of the same or nearby pits. Finally, the youngest dates around $6240 \mathrm{BC}$ and $6200 \mathrm{BC}$ appear in isolated pits, the latter farther apart in the southeast end of the excavated area. It should be noted that several pits were emptied and reused so the above chronological distribution across the site may not necessarily represent the complete history of habitation; nevertheless, it does show the use and management of the area by the inhabitants during 400 years of occupation. Thus, it seems that there was not a progressive use of specific parts of the area with time but rather a use of the whole excavated area right from the beginning and throughout the pit habitation period, perhaps with a movement towards the southeast during the latest phase.

The vertical dating within the pits also provides interesting information as it shows the length of use of each pit or its reuse after a period of time. Figure 13 shows the calibrated date distributions for pits from which we dated more than one sample. The pits are ordered from older to younger on the basis of the oldest date for each pit. The samples within each 
Revenia Pits $(\mathrm{Bl}=$ charcoal, blue=animal, red=human, magenta=seed OxCal v4.3.2 Bronk Ramsey (2017); r:5 IntCal13 atmospheric curve (Reimer et al 2013)

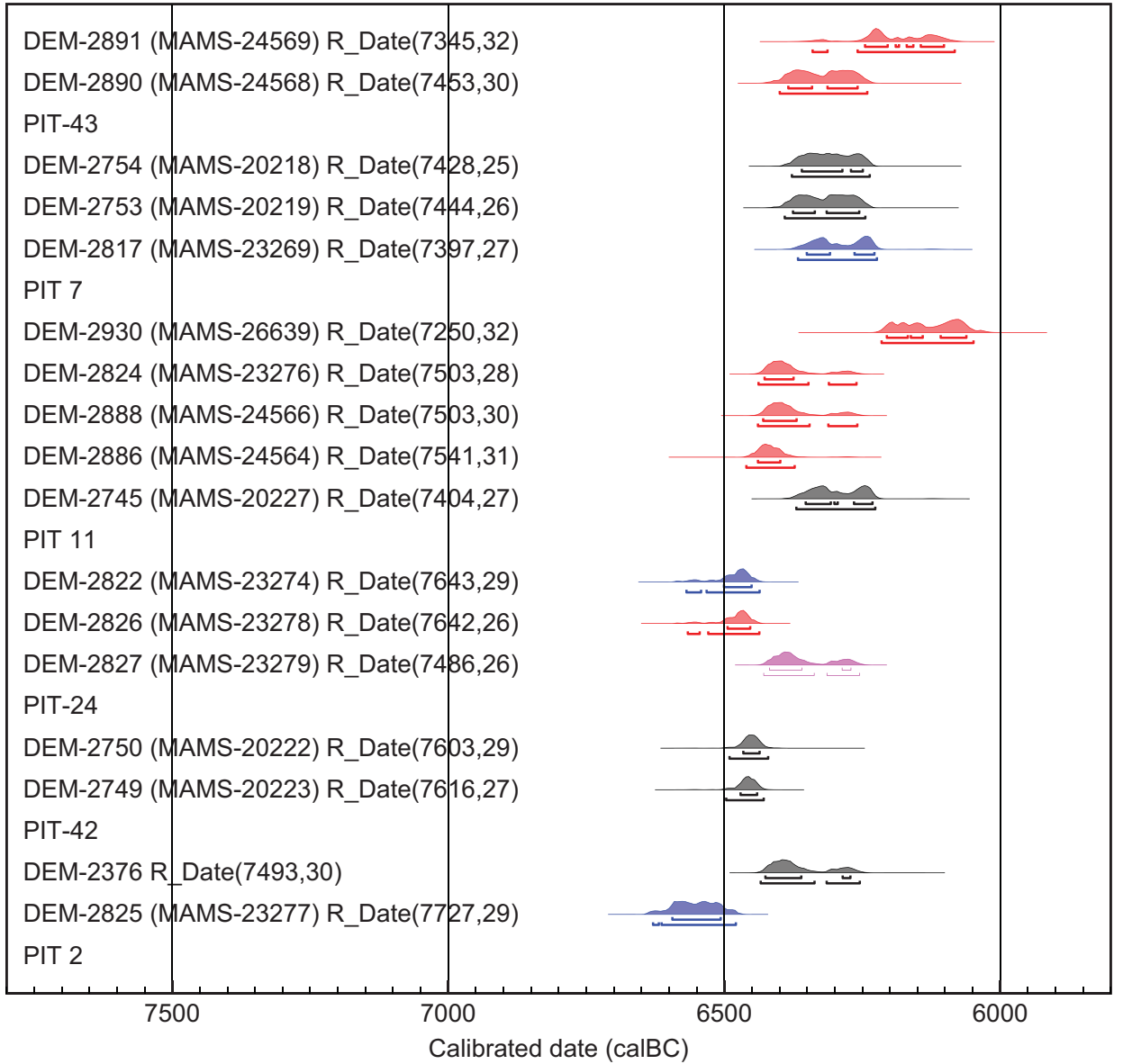

Figure 13 Distributions of calibrated dates of individual pits from which there were more than one sample analyzed. The samples in each pit are plotted according to stratigraphy, from deeper levels (lower in the plot) to higher levels. Color code: black $=$ charcoal; blue $=$ animal bone; red $=$ human bone; magenta $=$ seed. (Please see electronic version for color figures.)

pit are ordered from deeper (lower in the plot) to shallower depths. First, there are no differences or systematic shifts in dates between different materials (e.g., human bones, animal bones, and charcoal), indicating that we could exclude any old wood effect in the charcoal samples or diagenesis problems in the bones. There are two discrepancies in the sequence of events. The single seed (DEM-2827) in pit 24, coming from a deeper level in the pit, gives a younger age by about 100 years than the two bone samples above it. This discrepancy can be explained either by contamination of the seed (always a risk with a single seed) or its downward displacement from higher levels by water or microfauna. The latter is more likely since its age is not erroneous but coincides with a lot of other samples dating around $6400 \mathrm{BC}$, corresponding to the intensified period of occupation of the site. The second discrepancy concerns the charcoal sample DEM-2745 from pit 11, which yielded a total of five dates. This charcoal sample comes from the deepest level of the pit yet its age is about 100 years younger than the three human bone samples above it (DEM- 
2886, 2888, 2824), but older than the topmost human bone sample (DEM-2930). DEM-2745 consisted of several small charcoal fragments extracted from a mass of soil. The explanation for this discrepancy lies in the stratigraphic history of pit 11 which had a domestic use originally. The interruption and abandonment of the habitation use of this pit was followed by its filling up with various materials and its transformation into a funerary area. Concrete evidence of secondary manipulation of two of the four articulated burials, which provided samples DEM-2886 and DEM-2824, supports frequent mixing of the fill of the pit by the living (Triantaphyllou and Adaktylou 2019; for a general assessment of this issue see Chapman 2010; Chapman et al. 2014).

Apart from these two discrepancies, the dates within individual pits indicate that in some cases several layers were deposited in a short period of time (Pits 24, 42, 11, and 7), while some others seem to have been reused 100 or more years later (Pits 2, 7 again, and 43).

Sample DEM-2825 from pit 2 provided the earliest date from the settlement and came from the deepest layer of the pit, where its primary habitational phase is attested. Sample DEM-2376 from the same pit is dated later, as it came from the secondary, refuse use of the pit with the extraordinarily large quantities of the brackish-water cockle Cerastoderma glaucum. Pit $5 \gamma$ is remarkable, in terms of its size, depth and construction features. It is, in fact, the deepest access step (of three) to the subterranean part of habitation pit 5. The sample from pit $5 \gamma$ (DEM-2746) belongs to its secondary, refuse use and came just $0.05 \mathrm{~m}$ higher than the layer that preserves its habitation use, according to the stratigraphic history of the pit. Habitation pits 24 and 42 do not preserve their habitation use. Their secondary fills were rich in animal bones and chipped stone, ground stone and animal bone tools. Limb bones from pits 24 and 42 were intensively smashed to extract marrow and probably grease (Isaakidou et al. 2018). Habitation pit 11 has yielded six burials in total (four primary articulated inhumations and two bone accumulations), which took place after the habitational use of the pit, when the space was reused as funerary area, based on stratigraphic data (Adaktylou 2017: Vol. I, p. 70). The earliest human burial comes from pit 11 (DEM-2886), a woman aged 30-40 and included in the paleogenetic study discussed above. Habitation pits 7, 48 $\gamma$ and 44 were initially assigned to the earliest EN period, due to the almost exclusively monochrome pottery they contained. All samples from pits 7 (DEM-2753, 2754 and 2818) and 44 (DEM-2821) are dated to later phases (Figure 13, Table 1), whereas pit $48 \gamma$ (DEM-2751) indeed belongs to the earliest EN period. Of these pits, however, pit $48 \gamma$ alone preserves, according to its stratigraphy, its habitation use, while the fills of the other two appear to be the result of secondary, structured refuse deposition. Dates of the two burials from pit 43 are later than those from pit 11, although they both fall into the EN. Burial 6 (bone accumulation) from pit 43 is the latest of all burials (DEM-2891). In pit dwelling 26 the habitation layer was not preserved. This pit provided a very interesting faunal assemblage, as mentioned above, with cattle bones consistent with EN ploughing, as also in the chronologically early faunal assemblage from Knossos in Crete (Isaakidou 2006; Halstead and Isaakidou 2013: 131-133). One of these bones associated with an LEN context (DEM-2819) provided a mean modeled date of 6289 BC.

A note should be made here about pits 17, 18, 24, and 42, which as discussed earlier do not contain any chronologically diagnostic material culture; hence the samples coming from them cannot be classed into either of the two EN phases identified. Given that the first EEN phase lasts from about 6550 to 6430 BC (Table 2), samples DEM-2822 and 2826 (animal bone and human bone) from pit 24, DEM-2818 (animal bone) from pit 18, and DEM-2749 and 2750 
(charcoals) from pit 42, whose dates fall within this range (Table 1, Figure 8), should represent activity in the EEN period. On the other hand, sample DEM-2892 (scattered human bone) from pit 17 , whose $2 \sigma$ date of $6452-6265 \mathrm{BC}$ falls mostly after $6430 \mathrm{BC}$, must indicate the use of this pit in the more advanced period (LEN).

\section{CONCLUSIONS}

This study involved a systematic radiocarbon dating of Early Neolithic Revenia-Korinos, an open-air, flat-extended settlement in lowland Pieria, North Greece, $5 \mathrm{~km}$ from the present shoreline, a fertile estuarine location at the time. The samples were selected from the earlier habitation period of the site (i.e., the pits) to represent all types of pits and deposition phases and from different locations covering almost the whole of the excavated area. The results show that Revenia is one of the earliest Early Neolithic settlements in North Greece and the Aegean in general. It appears that this flat fertile land on alluvial deposits and close to the sea was a favorable environment for the first farmers and their farming and stock-breeding activities, as also observed for the majority of Early Neolithic sites. The earliest phase at Revenia, defined in Thessalian pottery terms as EEN, lasts around 100 years (radiocarbon mean modeled dates 6550-6430 BC) and is represented by a relatively low number of samples. Evidence for occupation becomes much richer around 6460/6430 BC when a more advanced phase begins, defined in Thessalian pottery terms as LEN, a pattern also observed at other Early Neolithic sites in North Greece. The apparent intensification of habitation in this phase inferred from the radiocarbon data and the establishment of new settlements around the Yannitsa plain in the same period perhaps reflect an expansion of population.

The subterranean or semi-subterranean pit dwellings were constructed in different parts of the site right from the beginning of the EEN, covering the whole excavated area and the same pattern continued during the LEN phase.

The life-cycle of the pits was quite complex (use, reuse, abandonment, filling up with various materials, occasional mixing of their fills, final sealing), so radiocarbon dating proved invaluable for ordering and clarifying the sequence of events inside the pits, habitation patterns, use of pits and burials. The case of habitation pit 11 is a good example of this, since radiocarbon dating made it possible to understand better the stratigraphic history of the pit, order its human burials chronologically and confirm frequent mixing of the fill of the pit by the living.

\section{ACKNOWLEDGMENTS}

This work was made possible through the generous funding for our Early Neolithic Radiocarbon dating project by the Institute for Aegean Prehistory (INSTAP) to which we are sincerely indebted.

We are grateful to Mr. Manthos Besios, co-excavator of the site, who provided facilities and invaluable support in all aspects of the work. Many thanks are also due to Professor Emeritus Kostas Kotsakis and Associate Professor Dushka Urem-Kotsou, who supervised the team studying the Revenia ceramics, and to the former also for valuable comments on a draft of this text. We also thank Professor Paul Halstead and Dr. Valasia Isaakidou, Associate Professor Sevi Triantaphyllou, Assistant Professor Maria Ntinou, and Dr. Georgia Kotzamani for selection of animal bone, human bone, charcoal, and seed samples, 
respectively, and Dr. Evangelia Kiriatzi, Director of the Fitch Laboratory at Athens, for facilitating the animal bone sampling. Finally, we would like to express our enormous thanks to Paul Halstead for his invaluable comments and thoughts in improving this manuscript and the anonymous reviewer for very helpful comments.

\section{BIBLIOGRAPHY}

Adaktylou F. 2017. The Neolithic settlement at Revenia, Korinos, Pieria (Vol. I \& II) [unpublished MA thesis]. Dept. of History and Archaeology, Aristotle University of Thessaloniki. In Greek.

Andreou S, Fotiadis M, Kotsakis K. 2001. Review of Aegean prehistory V: The Neolithic and Bronze Age of northern Greece. In: Cullen T, editor. Aegean prehistory. A review. American Journal of Archaeology, Supplement 1:259-327.

Besios M, Adaktylou F. 2006. The Neolithic settlement at "Revenia" Korinou (in Greek). In: Adam-Veleni P, Tzanavari K, editors. The archaeological work of Macedonia and Thrace 18 (2004). Thessaloniki. p. 357-366.

Bintliff J. 1976. The plain of Western Macedonia and the Neolithic site of Nea Nikomedeia. Proceedings of the Prehistoric Society 42: 241-262.

Bronk Ramsey C. 2009. Bayesian analysis of radiocarbon dates. Radiocarbon 51(1):337-360.

Bronk Ramsey C. 2017. Methods for summarizing radiocarbon datasets. Radiocarbon 59(2): 1809-1833.

Brown TA, Nelson DE, Vogel JS, Southon JR. 1988. Improved collagen extraction by modified Longin method. Radiocarbon 30(2):171-177.

Burger J, Thomas MG. 2011. The palaeopopulationgenetics of humans, cattle and dairying in Neolithic Europe. In: Pinhasi R, Stock JT, editors. Human bioarchaeology of the transition to agriculture. John Wiley \& Sons Ltd. Section D. Chapter 15. p. 371-384.

Chapman J. 2000. Pit-digging and structured deposition in the Neolithic and Copper Age. Proceedings of the Prehistoric Society 66: 61-87.

Chapman J. 2010. Deviant Burials in the Neolithic and Chalcolithic of Central and Southeast Europe. In: Rebay-Salisbury K, Sørensen K, Hughes ML, editors. Body parts and bodies whole, changing relations and meanings. Oxford: Oxbow Monographs. p. 30-45.

Chapman J, Wallduck R, Triantaphyllou S. 2014. Disarticulated human bone disposal during the Mesolithic, Neolithic and Chalcolithic in the Balkans and Greece. In: Gligor M, editor. Annales Universitatis Apulensis, Series Historica 18/II, Editura Mega. p. 11-45.

Colledge S, Conolly J, Shennan S. 2004. Archaeobotanical evidence for the spread of farming in the Eastern Mediterranean. Current Anthropology 45, Supplement:35-58.

de Vries H, Barendsen GW. 1953. Radiocarbon dating by a proportional counter filled with carbon dioxide. Physica 19:987-1003.

Dogiama L. 2017. Casting a wide network: preliminary results from the Early Neolithic chipped stone assemblages from Revenia, Pieria (Greece). In: Sarris A, Kalogiropoulou E, Kalayci Y, Karimali L, editors. Communities, landscapes, and interaction in Neolithic Greece. Proceedings of the International Conference. Rethymno 29-30 May 2015. International Monographs in Prehistory. Archaeological Series 20. p. 446-462.

Douka K, Efstratiou N, Hald MM, Henriksen PS, Karetsou A. 2017. Dating Knossos and the arrival of the earliest Neolithic in the southern Aegean. Antiquity 91(356):304-321.

Fernández E, Pérez- Pérez A, Gamba C, Prats E, Cuesta P, Anfruns J, Molist M, Arroyo-Pardo E, Turbón D. 2014. Ancient DNA Analysis of 8000 B.C. Near Eastern farmers supports an Early Neolithic pioneer maritime colonization of mainland Europe through Cyprus and the Aegean Islands. PLoS Genet 10(6): e1004401. doi: 10.1371/journal. pgen.1004401.

Gkouma M, Karkanas P. 2016. The physical environment in Northern Greece at the advent of the Neolithic. Quaternary International. doi: 10.1016/j.quaint.2016.08.034.

Haak W, Balanovsky O, Sanchez JJ, Koshel S, Zaporozhchenko V, Adler CJ, et al. 2010. Ancient DNA from European Early Neolithic farmers reveals their Near Eastern affinities. PLoS Biol 8(11): e1000536. doi: 10.1371/journal. pbio. 1000536 .

Halstead P. 2011. Farming, material culture and ideology: repackaging the Neolithic of Greece (and Europe). In: Hadjikoumis A, Robinson E, Viner S, editors. The dynamics of Neolithisation in Europe. Studies in honour of Andrew Sherratt. Oxford: Oxbow Books. p. 131-151.

Halstead P, Isaakidou V. 2013. Early stock-keeping in Greece. In: Colledge S, Conolly J, Dobney K, Manning K, Shennan S, editors. The origins and spread of domestic animals in Southwest Asia and Europe. Walnut Creek (CA): Left Coast Press, Inc. p. 129-143. 
Hansen JM. 1991. The palaeoethnobotany of Franchthi Cave. Excavations of Franchthi Cave, Fascicle 7. Bloomington (IN): Indiana University Press.

Hofmann D. 2015. What have genetics ever done for us? The implications of aDNA data for interpreting identity in Early Neolithic Central Europe. European Journal of Archaeology 18(3):454-476.

Hofmanová Z, Kreutzer S, Hellenthal G, Sell C, Diekmann Y, del Molino DD, van Dorp L, López S, Kousathanas A, Link V, Kirsanow K, Cassidy LM, Martiniano R, Strobel M, Scheu A, Kotsakis K, Halstead P, Triantaphyllou S, Kyparissi-Apostolika N, Urem-Kotsou DC, Ziota C, Adaktylou F, Gopalan S, Bobo DM, Winkelbach L, Blöcher J, Unterländer $\mathrm{M}$, Leuenberger $\mathrm{C}$, Çilingiroğlu Ç, Horejs B, Gerritsen F, Shennan S, Bradley DG, Currat $M$, Veeramah K, Wegmann D, Thomas MG, Papageorgopoulou C, Burger J. 2016. Early farmers from across Europe directly descended from Neolithic Aegeans. doi: 10.1073/pnas.1523951113.

Horejs B, Milic' B, Ostmann F, Thanheiser U, Weninger B, and Galik A. 2015. The Aegean in the early 7 th millennium $\mathrm{BC}$ : maritime networks and colonization. J World Prehist. 28:289-330.

Isaakidou V. 2006. Ploughing with cows: Knossos and the secondary products revolution. In: Serjeantson D, Field D, editor. Animals in the Neolithic of Britain and Europe. Oxford: Oxbow Books. p. 95-112.

Isaakidou V, Halstead P, Adaktylou F. 2018. Animal carcass processing, cooking and consumption at Early Neolithic Revenia-Korinou, northern Greece. Quaternary International. doi: 10.1016/ j.quaint.2018.05.040.

Karamitrou-Mentessidi G, Efstratiou N, Kozlowski JK, Kaczanowska M, Maniatis Y, Curci A, Michalopoulou S, Papathanasiou A, Valamoti SM, 2013. New evidence on the beginning of farming in Greece: the Early Neolithic settlement of Mavropigi in western Macedonia (Greece). Antiquity 87(336). http://antiquity.ac. uk/projgall/mentessidi336/

Kılınç MV, Koptekin D, Atakuman Ç, Sümer AP, Dönertaş HM, Yaka R, Bilgin CC, Büyükkarakaya AM, Baird D, Altınışık E, Flegontov P, Götherström A, Togan I, Mehmet Somel M. 2017. Archaeogenomic analysis of the first steps of Neolithization in Anatolia and the Aegean. Proceedings Royal Society B 284: 20172064. doi: 10.1098/rspb.2017.2064.

Kotsakis K. 2001. Mesolithic to Neolithic in Greece. Continuity, discontinuity or change of course? Documenta Praehistorica XXVIII, Neolithic Studies 8:63-73.

Kotsakis K. 2003. From the Neolithic side: the Mesolithic/Neolithic interface in Greece.
In: Galanidou N, Perlès C, editors. The Greek Mesolithic. Problems and perspectives, BSA, Studies 10. p. 217-221.

Kotsakis K. 2005. Across the border: unstable dwellings and fluid landscapes in the earliest Neolithic of Greece. In: Bailey D, Whittle A, Cummings V, editors. (Un) settling the Neolithic. Oxford: Oxbow Books. p. 8-15.

Kotsakis K. 2008. A sea of agency: Crete in the context of the Earliest Neolithic in Greece. In: Isaakidou V, Tomkins $\mathrm{P}$, editors. Escaping the Labyrinth. The Cretan Neolithic in Context. Oxford: Oxbow Books. Sheffield Studies in Aegean Archaeology. p. 52-75.

Kotsakis K. 2014. A hundred years of neolithic research in Macedonia: trends and directions (in Greek). In: Stefani E, Merousis N, Dimoula A, editors. A century of research in prehistoric Macedonia 1912-2012. International Conference Proceedings. Archaeological Museum of Thessaloniki, 22-24 November 2012. Thessaloniki. p. 133-140.

Kotsos S, Urem-Kotsou D. 2006. Filling in the Neolithic Landscape of Central Macedonia, Greece. In: Tasić N, Grozdanov C, editors. Homage to Milutin Garašanin, Belgrade. p. 193-205.

Kotzamani G. 2009. From gathering to cultivation: an archaeobotanical investigation of the early stages of plant exploitation and the beginnings of agriculture in Greece (Theopetra cave, Schisto cave, Sidari, Revenia) [unpublished $\mathrm{PhD}$ thesis]. Dept. of History and Archaeology, Aristotle University of Thessaloniki. In Greek.

Krahtopoulou A, Veropoulidou R. 2014. Linking inland and coastal records: landscape and human histories in Pieria, Macedonia, Greece. In: Touchais G, Laffineur R, Rougemont F, editors. PHYSIS 14 (11-14 décembre 2012, Paris). L'Environnement naturel et la relation homme-milieu dans le monde égéen Protohistorique. Peeters, Leuven-Liege. p. 153-158.

Krahtopoulou A, Veropoulidou R. 2016. Late Pleistocene-Holocene shoreline reconstruction and human exploitation of molluscan resources in northern Pieria, Macedonia, Greece. Journal of Archaeological Science: Reports. doi: 10. 1016/j.jasrep.2016.02.003.

Kromer B, Münnich KO. 1992. $\mathrm{CO}_{2}$ gas proportional counting in radiocarbon dating - review and perspective. In: Taylor RE, Long A, Kra RS, editors. Radiocarbon after four decades: an interdisciplinary perspective. New York: Springer-Verlag. p. 184-197.

Lazaridis I et al. 2016. Genomic insights into the origin of farming in the ancient Near East. Nature 536:419-424.

Lazaridis I et al. 2017. Genetic origins of the Minoans and Mycenaeans. Nature 548:214-230. 
Lespez L, Tsirtsoni Z, Darcque P, Malamidou D, Koukouli-Chryssanthaki H, Glais A. 2017. Identifying the Earliest Neolithic settlements in the southeastern Balkans. methodological considerations based on the recent geoarchaeological investigations at Dikili Tash (Greek Eastern Macedonia). In: Reingruber A, Tsirtsoni Z, Nedelcheva P, editors. Going West?: the dissemination of Neolithic innovations between the Bosporus and the Carpathians (Themes in Contemporary Archaeology). Chapter 4. Routledge: European Association of Archaeologists. doi: 10.4324/ 9781315230603-5.

Longin R. 1971. New method of collagen extraction for radiocarbon dating. Nature 230: 241-242.

Maniatis Y. 2014. Radiocarbon dating of the major cultural changes in Macedonia: Recent developments. In: Stefani E, Merousis N, Dimoula A, editors. International conference proceedings on a century of research in prehistoric Macedonia 1912-2012. Archaeological Museum of Thessaloniki, 22-24 November 2012, Thessaloniki. p. 205-222.

Maniatis G, Kotsakis K, Halstead P. 2015. Paliambela Kolindrou. New dates of the Early Neolithic in Macedonia (in Greek). In: AdamVeleni P, Tzanavari K, editors. The Archaeological Work of Macedonia and Thrace 25 (2011). Thessaloniki. p. 149-156.

Maniatis Y, Oberlin Ch, Tsirtsoni Z. 2016. "BALKANS 4000": the radiocarbon dates from archaeological contexts. In: Tsirtsoni Z, editor. The human face of radiocarbon, TMO 69, Maison de l'Orient et de la Méditerranée. Lyon. p. 41-65.

Mathieson I, et al. 2015. Genome-wide patterns of selection in 230 ancient Eurasians. Nature 528:499-514.

Mathieson I, et al. 2018. The genomic history of southeastern Europe. Nature 555:197-203.

Marinova E, Valamoti S-M. 2014. Crop diversity and choice in prehistoric southeastern Europe: cultural and environmental factors shaping the archaeobotanical record of Northern Greece and Bulgaria. In: Chevalier A, Marinova E and Peña-Chocarro L, editors. Plants and people: choices and diversity through time. Oxford: Oxbow Books. p. 64-74.

Paschou P, Drineas P, Yannaki E, Razou A, Kanaki K, Tsetsos F, Sampath Padmanabhunia S, Michalodimitrakis M, Rendae MC, Pavlovic S, Anagnostopoulos A, Stamatoyannopoulos JA, Kidd KK, Stamatoyannopoulos G. 2014. Maritime route of colonization of Europe. PNAS 111(25):9211-9216.

Perlès C. 2003. An alternative (and old-fashioned) view of Neolithisation in Greece. Documenta Praehistorica Neolithic Studies XXX:99-113.
Perlès C, Quiles A, Valladas H. 2013. Early seventhmillennium AMS dates from domestic seeds in the Initial Neolithic at Franchthi Cave (Argolid, Greece). Antiquity 87:1001-1015.

Reimer P, Bard E, Bayliss A, Beck W, Blackwell P, Bronk Ramsey C, Buck C, Cheng H, Edwards L, Friedrich M, Guilderson T, Haflidason H, Hatté C, Heaton T, Hogg A, Hofmann D, Hughen K, Kaiser F, Kromer B, Manning S, Niu M, Reimer R, Richards D, Scott M, Southon J, Staff R, Turney C, van der Plicht J. 2013. IntCal13 and Marine13 radiocarbon age calibration curves, 0-50,000 years cal BP. Radiocarbon 55(4): 1869-1887.

Reingruber A, Thissen L. 2009. Depending on ${ }^{14} \mathrm{C}$ data: chronological frameworks in the Neolithic and Chalcolithic of southeastern Europe. Radiocarbon 51(2):751-770.

Reingruber A, Toufexis G, Kyparissi-Apostolika N, Anetakis M, Maniatis Y, Facorellis Y. 2017. Neolithic Thessaly: Radiocarbon dated periods and phases. Documenta Praehistorica XLIV: $34-53$.

Stuiver M, Polach HA. 1977. Discussion: reporting of ${ }^{14} \mathrm{C}$ data. Radiocarbon 19(3):355-363.

Triantaphyllou S, Adaktylou F. 2019. The manipulation of the deceased during the earlier phases of the Neolithic period in Macedonia: first remarks from Revenia, Korinos, northern Pieria. In: Adam-Veleni P, Arvanitaki A, Zografou E, editors. The Archaeological Work of Macedonia and Thrace 28 (2014). Thessaloniki. p. 215-222. In Greek.

Urem-Kotsou D, Papaioannou A, Papadakou T, Saridaki N, Intze Z. 2014. Pottery and stylistic boundaries. Early and Middle Neolithic pottery in Macedonia. In: Stefani E, Merousis N, Dimoula A, editors. A century of research in prehistoric Macedonia 1912-2012. International Conference Proceedings. Archaeological Museum of Thessaloniki, 22-24 November 2012. Thessaloniki. p. 505-517.

Urem-Kotsou D, Dimoula A, Elezi G, Papadakou T, Papaioannou A, Saridaki N, Siamidou I, Silva T, Tzemopoulou E, Kotsakis K. 2017. Patterns in contemporaneous ceramic traditions: interregional relations between Thessaly and Macedonia during the Early and Middle Neolithic. In: Sarris A, Kalogiropoulou E, Kalayci Y, Karimali L, editors. Communities, landscapes, and interaction in Neolithic Greece, proceedings of the international conference. Rethymno, 29-30 May 2015. International Monographs in Prehistory, Archaeological Series 20:324-338.

Valamoti S-M, Kotsakis K. 2007. Transitions to agriculture in the Aegean: the archaeobotanical evidence. In: Colledge S, Conolly J, editors. The origins and spread of domestic plants in 
Southwest Asia and Europe. Walnut Creek (CA): Left Coast Press. p. 75-92.

Weiss E, Zohary S. 2011. The Neolithic Southwest Asian founder crops. Their biology and archaeobotany. Current Anthropology 52 (Supplement 4):237-254.

Wilkie NC, Savina ME. 1997. The earliest farmers in Macedonia. Antiquity 71:201-207.
Zeder MA. 2009. Evolutionary biology and the emergence of agriculture: the value of co-opted models of evolution in the study of culture change. Chapter 6. In: Prentiss AM et al. editors. Macroevolution in human prehistory. New York: Springer. p. 157-210. https://link.springer.com/chapter/10. 1007/978-1-4419-0682-3_7 